\title{
Coupling eruption and tsunami records: the Krakatau 1883 case study, Indonesia
}

\author{
Raphaël Paris • Patrick Wassmer • Franck Lavigne • Alexander Belousov • \\ Marina Belousova - Yan Iskandarsyah • Mhammed Benbakkar • Budianto Ontowirjo • \\ Nelly Mazzoni
}

Received: 14 October 2013 / Accepted: 18 February 2014

(C) Springer-Verlag Berlin Heidelberg 2014

\begin{abstract}
The well-documented 1883 eruption of Krakatau volcano (Indonesia) offers an opportunity to couple the eruption's history with the tsunami record. The aim of this paper is not to re-analyse the scenario for the 1883 eruption but to demonstrate that the study of tsunami deposits provides information for reconstructing past eruptions. Indeed, though the characteristics of volcanogenic tsunami deposits are similar to those of other tsunami deposits, they may include juvenile material (e.g. fresh pumice) or be interbedded with distal pyroclastic deposits (ash fall, surges), due to their simultaneity with
\end{abstract}

Editorial responsibility: S. Self

Electronic supplementary material The online version of this article (doi:10.1007/s00445-014-0814-x) contains supplementary material, which is available to authorized users.

R. Paris $\cdot$ M. Benbakkar

Clermont Université, Université Blaise Pascal, BP 10448,

63000 Clermont-Ferrand, France

R. Paris $(\varangle) \cdot$ M. Benbakkar

Magmas et Volcans, CNRS, UMR 6524, 63038 Clermont-Ferrand,

France

e-mail: R.Paris@opgc.univ-bpclermont.fr

P. Wassmer $\cdot$ F. Lavigne

UMR 8591, Laboratoire de Géographie Physique, CNRS,

92195 Meudon, France

P. Wassmer

Faculté de Géographie et d'Aménagement, Université de Strasbourg,

Strasbourg, France

F. Lavigne

Université Paris 1 Panthéon-Sorbonne, PRES HESAM, Meudon,

France the eruption. Five kinds of sedimentary and volcanic facies related to the 1883 events were identified along the coasts of Java and Sumatra: (1) bioclastic tsunami sands and (2) pumiceous tsunami sands, deposited respectively before and during the Plinian phase (26-27 August); (3) rounded pumice lapilli reworked by tsunami; (4) pumiceous ash fall deposits and (5) pyroclastic surge deposits (only in Sumatra). The stratigraphic record on the coasts of Java and Sumatra, which agrees particularly well with observations of the 1883 events, is tentatively linked to the proximal stratigraphy of the eruption.
Y. Iskandarsyah

Laboratorium Geologi Lingkungan dan Hidrogeologi, Fakultas Teknik Geologi, Universitas Padjadjaran (UNPAD), Bandung, Indonesia

Y. Iskandarsyah

Laboratoire Image, Ville, Environnement (LIVE), UMR 7362

CNRS, Université de Strasbourg, Strasbourg, France

N. Mazzoni

Clermont Université, GEOLAB, Université Blaise Pascal, BP 10448, 63000 Clermont-Ferrand, France

N. Mazzoni

GEOLAB, UMR 6042, CNRS, 63057 Clermont-Ferrand, France

B. Ontowirjo

BPDP BPPT, Jakarta 10340, Indonesia 
Keywords Volcanic tsunami $\cdot$ Tsunami deposits $\cdot 1883$ Krakatau eruption · Pyroclastic fall · Pyroclastic surge . Indonesia

\section{Introduction}

Past volcanic eruptions can be reconstructed by analysing historical documents and characterising primary volcanic products in terms of thickness, componentry, texture, fragmentation, temperature of emplacement, crystal chronometry, etc. When tsunami waves are generated during a volcanic eruption, some primary volcanic deposits should be stratigraphically associated with tsunami deposits, thus adding more constraints for inferring the succession of the events and for geological interpretations. The generation of so-called volcanic tsunami by eruptive, intrusive and gravitational processes is more than anecdotal, and tsunami are implied in producing several of the worst volcanic disasters (Latter 1981; Begét 2000), including those of the Late Bronze Age eruption of Santorini Island in the Aegean Sea, the 1792 flank collapse of Mayuyama dome near Unzen volcano in Japan and the 1883 eruption of Krakatau volcano in Indonesia. Volcanic tsunamis are characterised by short-period waves and greater dispersion compared to earthquake-generated tsunamis, but they clearly expand the potential damage area of many volcanoes (Paris et al. 2013). The aim of this contribution is to document the sedimentary record of the 1883 Krakatau tsunamis on Java and Sumatra coasts (Fig. 1), and to demonstrate that tsunami deposits have the potential to allow complete reconstruction of past eruptions and their tsunamigenic processes.

The 1883 eruption and tsunamis that devastated the coasts of the Sunda Strait are particularly well documented, thanks to hundreds of observations and eyewitness accounts that were collected during and after the disaster (Verbeek 1886; Symons 1888; Simkin and Fiske 1983). The eruptive processes, and the source and time propagation of the tsunamis have been widely debated on the basis of observations, analysis of nearfield $(<20 \mathrm{~km}$ from Krakatau volcano) pyroclastic deposits, tide and pressure gauge records, and numerical modelling (Verbeek 1886; Stehn 1929; Williams 1941; Ewing and Press 1955; Latter 1981; Self and Rampino 1981; Yokoyama 1981, 1987; Camus and Vincent 1983; Francis 1985; Self 1992; Nomanbhoy and Satake 1995; Carey et al. 1996; Mandeville et al. 1996a, b; Choi et al. 2003; Pelinovsky et al. 2005; Maeno and Imamura 2011). This paper does not attempt to re-analyse the 1883 eruption and question the source of the tsunamis. It is now commonly accepted that (1) tsunamis occurred throughout the paroxysmal August 2627 eruption; (2) several processes could have produced tsunamis (landslide, pyroclastic flow entering seawater, caldera collapse, shock wave produced by large explosion); (3) most
Fig. 1 Maps showing distribution of 1883 Krakatau tsunamis, pyroclastic surges and ash fall deposits in Sunda Strait region (Indonesia), after previous works on tsunami deposits by Williams (1941), Ongkosongo (1983), Bronto (1990), Carey et al. (2001) and Van den Berg et al. (2003). Distribution of coral boulders after Umbgrove (1947), Verstappen (1956) and Setjaatmadja (2007). Typical tsunami wave propagation time in Sunda Strait (in minutes) was estimated by Yokoyama (1981), Giachetti et al. (2012) and Maeno and Imamura (2011)

of the pyroclastic flows were discharged into the sea with water depths up to $40 \mathrm{~m}$, thus (4) generating tsunamis of increasing magnitude from the afternoon 26 August to the morning 27 August and (5) pyroclastic surges travelled over water and impacted the southern coast of Sumatra.

The temporal order of the different processes is recorded in the strata of the proximal pyroclastic deposits (Stehn 1929; Williams 1941; Self and Rampino 1981; Mandeville et al. 1996b). Moderate explosive activity from May 20 to early August is represented by ash-fall deposits overlying the 1883 soil horizon. Onset of the Plinian August 26-27 phase is evidenced by coarse pumice fall deposits interbedded with surge and small pyroclastic flow deposits. In the early morning of 27 August, activity shifted from a convecting to a collapsing column, thus producing massive accumulations of pyroclastic flow deposits. Co-ignimbrite lag breccias in the upper part of the 1883 stratigraphic record might reflect the onset of caldera collapse. Investigations by Carey et al. (1996) and Mandeville et al. (1996b) on the islands north of Krakatau (Sebesi, Sebuku, Lagoendi) and offshore (SCUBA cores) illustrate the segregation of pyroclastic flows into a subaqueous high-concentration component and a dilute component traveling over water up to $80 \mathrm{~km}$ from the volcano. The culminating 10:00 AM explosion was followed by mud rain that lasted more than $2 \mathrm{~h}$ (Verbeek 1886). Mud rain was interpreted by Self and Rampino (1981) as a consequence of phreatomagmatic explosions when pyroclastic flows were discharged into the sea, but Carey et al. (1996) argued for a large co-ignimbrite ash plume.

Less attention was paid to the deposits left inland by the tsunami waves. Coral boulders interpreted as 1883 remnants were mentioned on the coasts of Java and Sumatra (Fig. 1), from Ujung Kulon Peninsula (Umbgrove 1947, Verstappen 1956) to Anyer (Verbeek 1886; Setjaatmadja 2007) and Gubug Garam (Setjaatmadja 2007). Photographs from the archives of the Royal Institute for the Tropics, Amsterdam, illustrate devastated landscapes covered by debris (coral boulders, pumices, fragments of buildings, trees, etc.). Remnants of a lighthouse (so-called 4th Point Java) were found up to $4 \mathrm{~km}$ inland along the Cikoneng River (near Anyer, Java). The largest coral boulder reported in Anyer by Verbeek (1886) had an approximate weight of $200 \mathrm{t}$, which is in the range of the largest coral boulders moved by tsunamis (e.g. Terry et al. 2013). Ongkosongo (1983) and Bronto (1990) briefly 


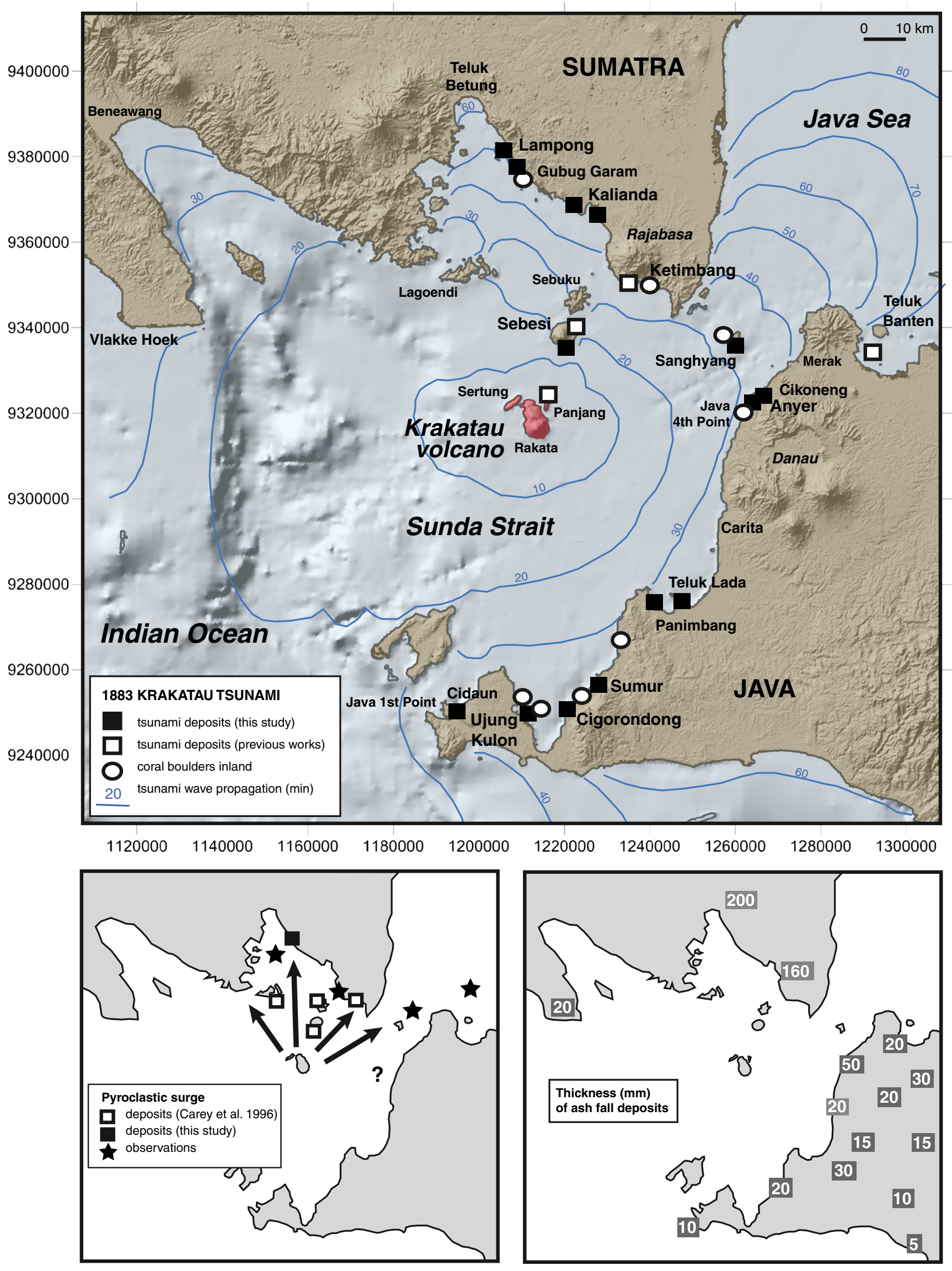


described the 1883 tsunami deposits in Java and Sumatra as unsorted and structureless gravel overlying pyroclastic deposits, but few details are given on the composition and emplacement of the deposits. Carey et al. (1996, 2001) studied the 1883 pyroclastic flow deposits on the islands north of Krakatau (Sebesi, Sebuku). Units of rounded pumice lapilli intercalated between the pyroclastic flow deposits are interpreted as floating pumice rafts reworked and left inland by tsunami. They also mentioned poorly sorted, silty to sandy deposits with corals and pumice on Sebesi Island and Sumatra (Fig. 1). Williams (1941) mentioned "a topmost unit consisting of lithic blocks, sediments, corals and shells" on Rakata, Panjang (Lang) and Sertung (Verlaten) islands, but he did not suggest a possible tsunami origin. This unit does not appear on the stratigraphic columns described by other authors (e.g. Stehn 1929; Mandeville et al. 1996a, b). The 1883 Krakatau main tsunami (originated at 10:00 AM of 27 August) is apparently recorded in submarines cores off Teluk Banten (Java Sea), as evidenced by Van den Berg et al. (2003) who identified a poorly sorted, sandy layer with abundant bioclasts, pumices and the typical 1883 crystal assemblage (plagioclase, green augite, brown hypersthene and magnetite). Land-derived components were locally transported into the shallow bay by the tsunami backwash (outflow).

\section{Methods}

Observations of the 1883 events compiled in the reports of Verbeek (1886) and Symons (1888), and in the later review of Simkin and Fiske (1983) were entered into a georeferenced database with links to the original text and integrated into a GIS (Geographic Information System). Data can be sorted by thematic, geographical or chronological requests (e.g. all tephra fall information in Java from 4:00 to 9:00 PM of 26 August 1883). Thematic files were prepared to be viewed with Google Earth (e.g. kml files of tsunami observations, tephra falls, explosions etc.). The scenario of the events at a precise location can thus be compared with the stratigraphic record. Thirteen types of observation were distinguished: earthquakes, eruptive activity at the vents (e.g. explosions, pyroclastic flows), airwaves (generated by the major explosions), pyroclastic falls, mud rain, darkness, optical effects, thunder/ lightning, smell of gas, floating pumice, tsunami, destruction of objects and fatalities. ArcGIS shapefiles and Google Earth $\mathrm{kml}$ files will be soon available at http://www.obs.univbpclermont.fr/lmv/pperm/paris_r/index.php.

Four surveys were carried out along the coasts of the Sunda Strait in January 2009, August 2010, August 2011 and October 2011, from Bandar Lampung (present name of Teluk Betung, Sumatra) to Ujung Kulon National Park (Java), including Sanghyang, Sebesi and Sertung islands
(Fig. 1). More than 50 trenches were dug or refreshed, and hundreds of samples collected. Well-preserved sedimentary sequences deposited by the 1883 events were found at only 15 sites. Indeed, the 1883 tsunami and primary volcanic deposits are not preserved everywhere, and are often reworked through bioturbation, slope processes, fish farming, tourist resorts, agriculture and industries (e.g. Merak, Labuhan, Bandar Lampung). All samples were analysed using a binocular microscope for estimating the proportions of marine bioclasts and 1883 volcanic juveniles (pumice, glass shards and fresh crystals). We also sampled pyroclastic deposits of the 1883 eruption in Panjang and Rakata islands (Fig. 1).

Tsunami deposits are usually characterised using a multidisciplinary approach, including sedimentological, micropalaeontological, geochronological and geochemical methods (e.g. Dawson and Stewart 2007; Bourgeois 2009; Goff et al. 2012; Keating et al. 2011). Cuven et al. (2013) used a combination of sedimentological (grain size, sorting, anisotropy of magnetic susceptibility), micromorphological (X-ray tomography and radiography, thin sections) and geochemical analysis (X-ray microfluorescence, ICP-AES, loss on ignition) to provide a comprehensive reconstruction of the different phases of the 1755 tsunami deposition and flow dynamics in Andalusia (Spain). The same suite of methods cannot be applied entirely to the 1883 Krakatau tsunami deposits. Grain size distributions were obtained for some selected units (e.g. sandy deposits in West Java, pumice lapilli in Sumatra), but most of the sediments sampled had a wide range of clast size (from silts to cobbles) and clast shape (e.g. coral gravels) and were not processed for granulometry. Because of the mixture of clasts, we also chose not to undertake X-ray tomography (cores in carbon tubes) or microfluorescence (half cores) studies.

We were able to collect samples for anisotropy of magnetic susceptibility (AMS) at only four sites, because for AMS the sediments must be fine (clay, silt and fine sand fractions) and have good cohesion. Samples were collected along vertical sections into 2-cm sided boxes, as described in Wassmer et al. (2010), who demonstrated that AMS can be used on unconsolidated tsunami deposits to gain information about sediment fabrics and depositional processes. Each sample was analysed in 15 directions using a Kappabridge KLY-2 in order to determine the magnitude and direction of the maximum, intermediate, and minimum AMS axes. The anisotropy of each sample (i.e. each cubic box) can be visualised by a triaxial ellipsoid (the maximum, intermediate and minimum axes corresponding to principal eigenvectors). The projection of AMS tensor axes onto a diagram of the lower hemisphere equal areas gives information on the influence of paleocurrents on the preferential orientation of the long axis of particles (grains). The calculation of AMS parameters such as magnetic lineation (L), foliation (F), alignment parameter (Fs) and shape parameter ( $\mathrm{T}$ ) allow relationships between 
magnetic fabrics and depositional processes to be evaluated. The alignment parameter represents the development of a linear fabric and thus increases with bottom current strength. The shape parameter describes the geometry of the AMS ellipsoid, which is oblate for $T>0$ (settling mode) or prolate for $T<0$ (traction mode). It has been demonstrated that the mean orientation of the grains long axes (and thus the maximum tensor axis $K_{\max }$ ) is parallel to flow direction for moderate currents and settling from suspension (e.g. Wassmer et al. 2010). For stronger currents with dominant traction (bed load), the long axis of prolate particles (and the $K_{\max }$ ) tends to be orientated perpendicular to flow direction.

Seventeen bulk samples of tsunami deposits, 13 samples of 1883 pyroclastic deposits (selected pumices) and four samples of older regional ignimbrites were analysed by ICP-AES (Jobin-Yvon ULTIMA C) for concentrations of major elements. This method allows (1) comparison with XRF analyses of 1883 whole-rock samples published by Self (1992) and Mandeville et al. (1996a, b); (2) and distinguishing between the 1883 Krakatau pumice and other regional sources of pumice that crop out along the coasts of Java and Sumatra (e.g. Danau caldera, Rajabasa volcano). Water, organic and carbonate content were estimated by loss on ignition (LOI) for $12 \mathrm{~h}$ at $105^{\circ} \mathrm{C}, 4 \mathrm{~h}$ at $550^{\circ} \mathrm{C}$ and $2 \mathrm{~h}$ at $950{ }^{\circ} \mathrm{C}$, respectively.

\section{Results}

Stratigraphy and composition of the deposits

Stratigraphic sections are described by geographical sectors, from the westernmost point of Java (Ujung Kulon) to Lampong Bay (Sumatra). In all the sections described, pumices, glass shards, dark olive obsidian and fresh crystals were identified. Three kinds of pumices can be distinguished: (1) highly vesicular white pumice emitted during the climactic stage (27 August 1883), representing $85 \%$ of the erupted products (Mandeville et al. 1996a); (2) highly vesicular light pink to dark grey pumice and (3) banded pumice. The most abundant crystals are tabular plagioclase and orthopyroxene (rhombic brown hypersthene, up to $4 \mathrm{~mm}$ in length and bronzite), but there are also monoclinic clinopyroxene and oxides (titanomagnetite, ilmenite), as in the 1883 primary pyroclastic deposits (Verbeek 1886; Williams 1941; Camus et al. 1987; Mandeville et al. 1996a). These criteria helped us identify 1883 primary or reworked volcanic deposits in the stratigraphy.

\section{Ujung Kulon}

Trenches $250 \mathrm{~m}$ from the north-eastern shoreline of the Ujung Kulon National Park (West Java, Fig. 1) display the following stratigraphy, from base to top (Fig. 2a). At a depth of $50 \mathrm{~cm}$, coral cobbles and gravels are mixed with medium-grained sands and marine bioclasts ( $4 \mathrm{wt} \%$ carbonates estimated by LOI at $950{ }^{\circ} \mathrm{C}$ ). Sand grains are subrounded to subangular, and their dominant shiny surfaces indicate that the main sediment source was a beach (Cailleux and Tricart 1959). We were not able to dig deeper and reach the 1883 surface. From 45 to $32 \mathrm{~cm}$ depth, this medium-grained sand is considerably enriched in dark heavy minerals. A 3-cm thick unit of lenticular coarse sand with fresh crystals, shells and coral fragments was found at a depth of $40 \mathrm{~cm}(12 \mathrm{wt} \%$ LOI at $950{ }^{\circ} \mathrm{C}$ ). Above $32 \mathrm{~cm}$ lies a 10 -cm thick unit of poorly sorted coarse sands, rich in bioclasts (mostly shell and coral fragments, $9 \mathrm{wt} \% \mathrm{LOI}$ at $950{ }^{\circ} \mathrm{C}$ ), in a clayey matrix including very fine pumices in low abundance. At $20-\mathrm{cm}$ depth, a discontinuous layer of light grey ash with rounded pumice lapilli and fresh crystals. It is overlain by a unit of coarse sand with abundant fine pumice ( $48 \%$ of the grains), fresh crystals $(30 \%)$ and bioclasts (12\% using the binocular microscope, $13 \mathrm{wt} \%$ LOI at $950^{\circ} \mathrm{C}$ ). Coral boulders up to $80 \mathrm{~cm}$ wide rise from the top of this sequence, covered by the post-1883 soil.

Other sites were investigated further north (Cidaun, Fig. 2b). The stratigraphy of the $3.5-\mathrm{m}$ thick sequence can be simplified as a succession of (1) volcanic pumiceous ash and lapilli and (2) sand units with coral gravels, showing enrichment in volcanic material upward. Sand units between 315 and $245 \mathrm{~cm}$ deep are very poorly sorted, enriched in coral and shell fragments and have rip-up clasts of clay at the base (Fig. 2b). These first sands are overlain by a greyish ash $(245-210 \mathrm{~cm})$ with numerous dark minerals and charcoal fragments. The second sand unit is composed of a lower layer $(210-180 \mathrm{~cm})$ of fine sands with marine bioclasts and pumiceous ash and an upper layer (180-156 cm) of fine sand mixed with brown silt. From 156 to $125 \mathrm{~cm}$, there is a light grey ash, with pumice lapilli and other fragments of volcanic rock (lithics). The third sand unit $(125-45 \mathrm{~cm})$ is yellowish, poorly sorted, mixed with pumiceous ash and lapilli, and marine bioclasts. Three layers can be distinguished, with an increasing abundance of pumice and decreasing abundance of bioclasts upward.

\section{Sumur}

A 380-m-long transect of 10 trenches was established near the village of Sumur (Fig. 1), from the coast to vegetated dunes near the road. The orientation of the transect (NNW-SSE) corresponds to the inferred flow direction of a tsunami coming from Krakatau volcano. Deposits of the 1883 events are here intercalated between the coral calcirudite and dune sands. The stratigraphy can be summarised as follows (Fig. 3): (1) bioclastic very coarse sand to gravel, without any evidence of fresh volcanic material; (2) coarse sand with marine bioclasts $(40-50 \%)$ and fine pumice (40\%) in a clayey-ashy matrix (corresponding to weathered volcanic ash); (3) discontinuous yellowish fine sand with abundant pumice but less bioclasts 
A Ujung Kulon - NE coast

UTM 48S 544401 / 9253786

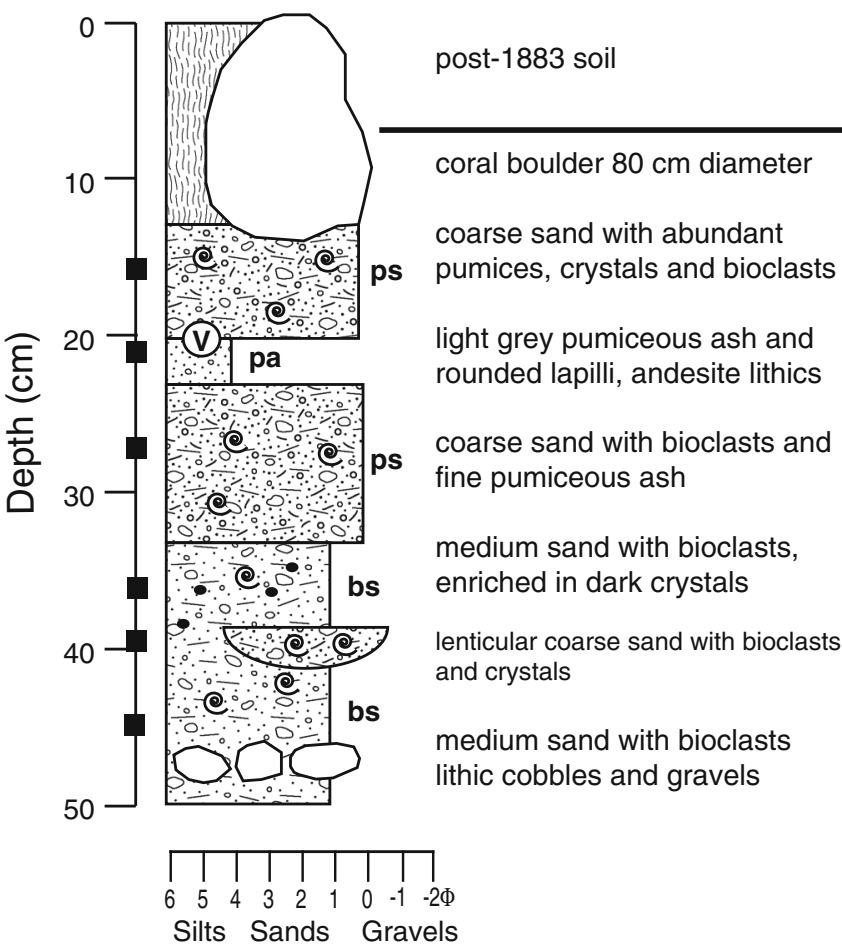

(e) marine bioclasts

• dark heavy minerals

rip-up clasts

(v) erosive contact

LOI \& ICP-AES samples

$\square \quad$ AMS samples

bs bioclastic sand: post-paroxysm tsunami deposits (26 August 1883)

pa pumiceous ash: primary pyroclastic fall deposits

pa@ pumiceous ash reworked by tsunami

ps pumiceous sand: paroxysm tsunami deposits (26-27 August 1883)

rpl rounded pumice lapilli: pyroclasts reworked by tsunami

pys primary pyroclastic surge deposits
B Ujung Kulon - Cidaun

UTM 48S 562837 / 9369102

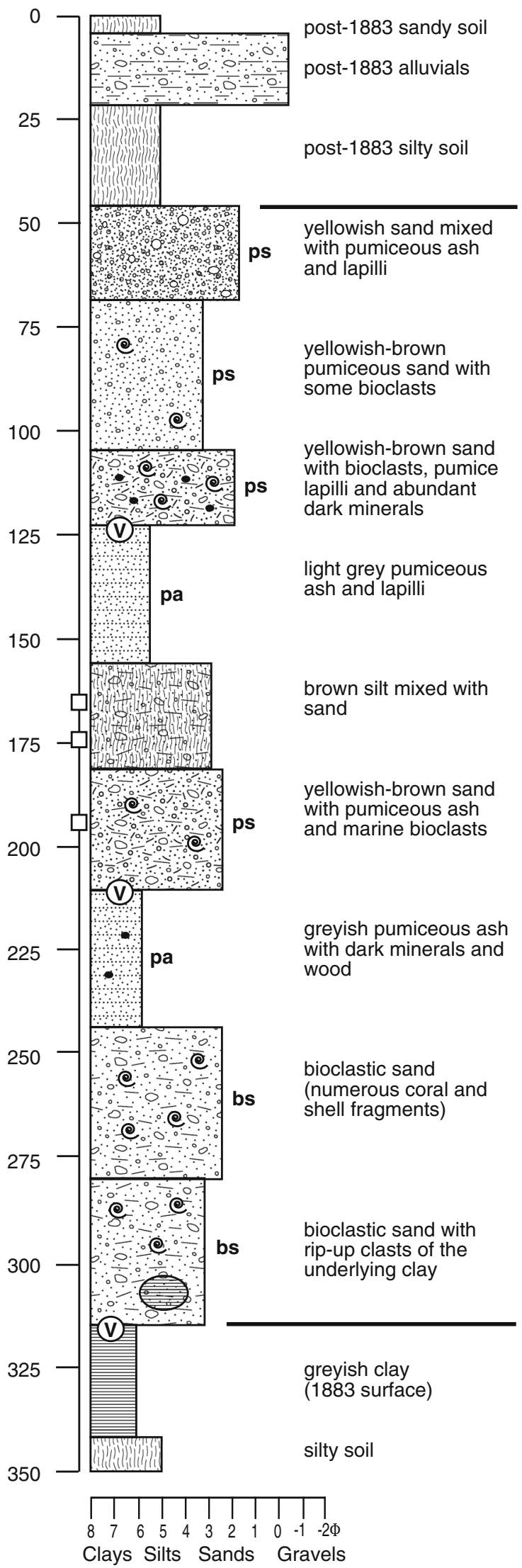


Fig. 2 Stratigraphic logs of Ujung Kulon peninsula (SW Java). The 1883 sequence is delimited by thick lines when lower and upper contacts are identified (see text for details)

$(<20 \%)$ and wood; and (4) thick unit $(20-30 \mathrm{~cm})$ of coarse sand to gravel with abundant pumice (including rounded lapilli), glass shards, obsidian and coarse bioclasts $(<25 \%)$. Juvenile volcanic material (i.e. from the 1883 eruption) represents up to $80 \%$ of this fourth unit. A rounded cobble of irregularly vesicular pumice was found in unit 4 at $380 \mathrm{~m}$ from the shoreline (Fig. 3). Units 1, 2 and 4 are particularly rich in marine macrofauna, especially gastropods (e.g. Cancellaria, Ceithium, Columbella, Architectonica, Natica, Tridacna). All units identified are poorly sorted, with inverse grading observed in units $1(80-70 \mathrm{~cm})$ and $4(45-15 \mathrm{~cm})$.

\section{Cigorondong}

On the road from Sumur to Cigorondong (UTM 48S, 559370/ 9257852), trenches revealed the presence of a $20-\mathrm{cm}$ thick tephra unit between a depth of 80 and $100 \mathrm{~cm}$. It is a white pumiceous ash with angular lapilli and fresh crystals (mostly plagioclase). No vertical grading was detected. Below the tephra, we found a thick unit of yellowish coarse sand with coarse bioclasts, obsidian and very fine pumices. As in Sumur, the substratum is a coral calcirudite. The tephra unit is overlain by coarse sand with pumiceous ash, light grey rounded pumice lapilli and wood fragments. Surprisingly, we could not find marine bioclasts in this upper unit. As in Ujung Kulon, coral boulders (up to $3 \mathrm{~m}$ ) are set in the uppermost part of the sequence.

\section{Panimbang}

A sequence of pumiceous sands is preserved near the shore $15 \mathrm{~km}$ WSW of Panimbang (Fig. 1), fossilising the 1883 soil (Fig. 4). The lower part of the sequence is a thick $(\sim 20 \mathrm{~cm})$, massive sand unit with a bimodal grain size distribution (sample 1 in Fig. 4; $50 \%$ medium-sized beach sand mixed with $50 \%$ very fine pumices). The upper part is
Fig. 3 Stratigraphic log of Sumur section (SW Java). Photograph: pumice bomb found in the upper pumiceous sand unit. See Fig. 2 for legend

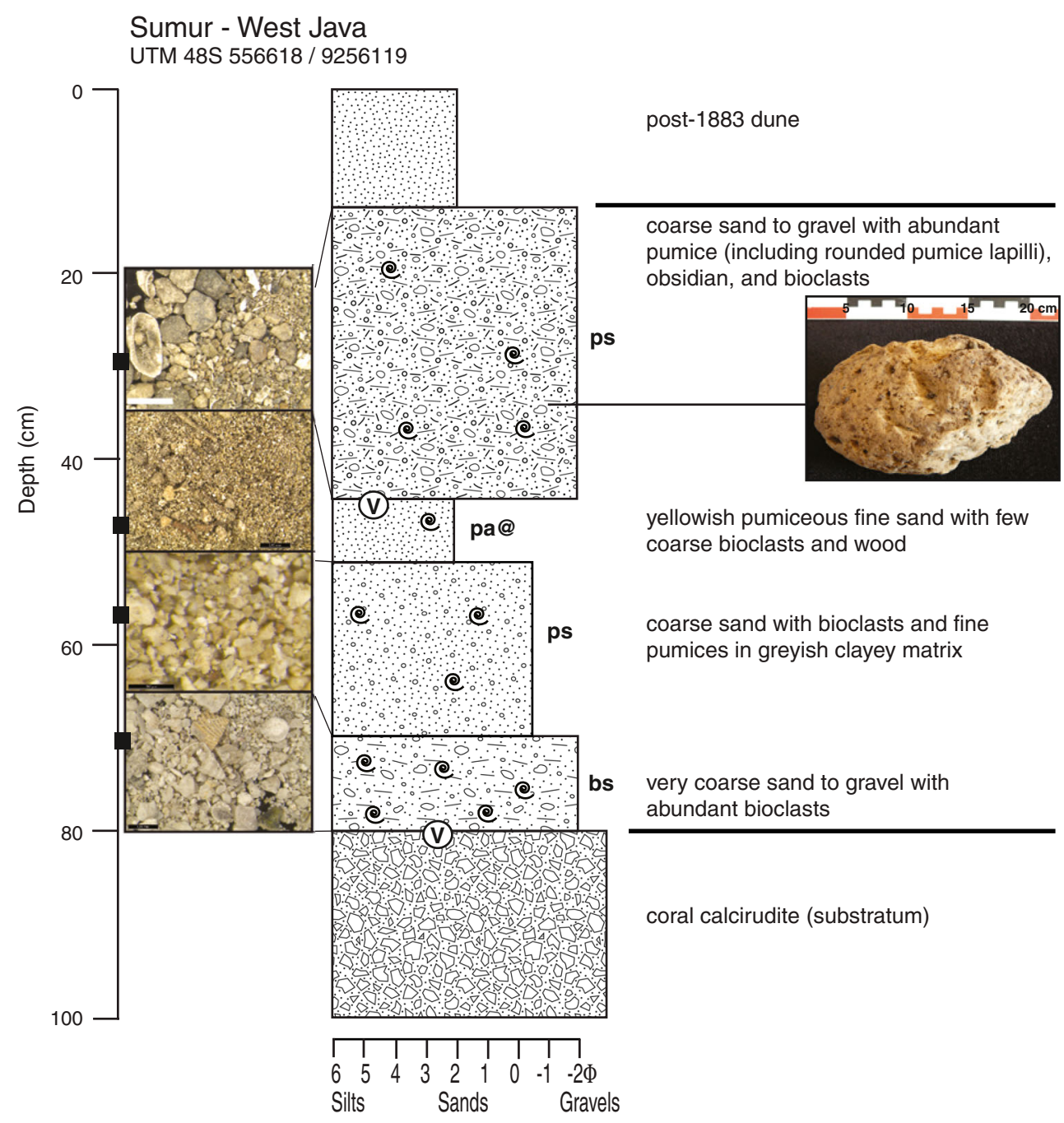


Fig. 4 Sampling and grain size distribution (GSD) of 1883

tsunami deposits near Panimbang (West Java, UTM 48S, 575746/ 9279408). Two populations can be distinguished in the GSD (separated by dashed line): fine volcanic ash in the coarse silt to very fine sand fractions, and medium to coarse sand from the beach, with coarse bioclasts (shells $>1 \mathrm{~mm}$ ). Grain size analysis was carried out using a laser-diffraction particle analyser (Coulter LS100)
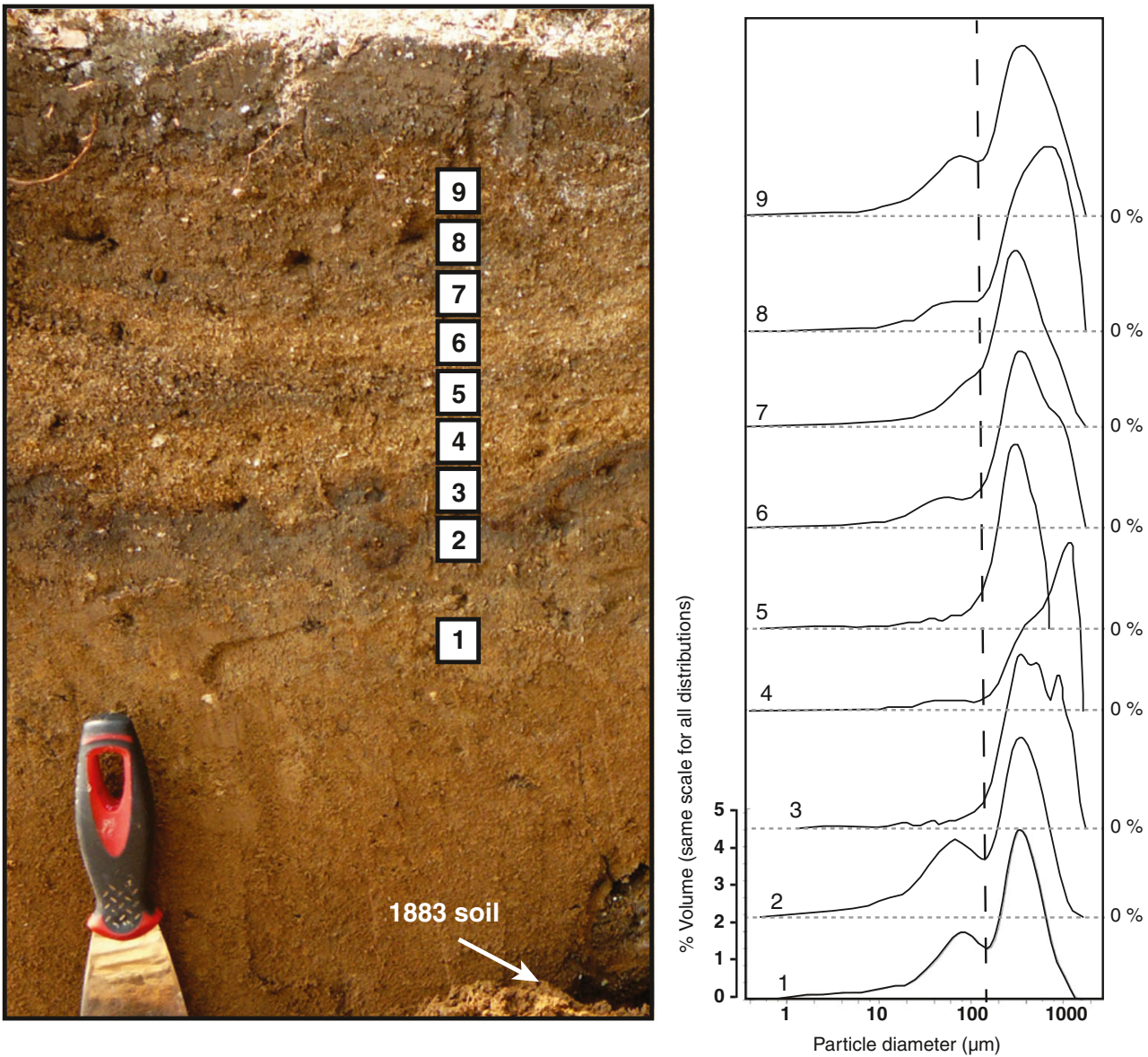

a laminated accumulation of coarse sand with bioclasts and small rounded pumice lapilli (e.g. samples 4 and 5), more or less enriched in very fine ash which forms clayey aggregates (e.g. sample 2). The contact between the lower and upper part of the sequence is associated with a very fine deposition of ash and charcoal, eroded by the upper laminated sands. Grain size distributions and observations with the binocular microscope allow two populations to be distinguished: (1) fine volcanic ash in the coarse silt to very fine sand fractions and (2) medium to coarse sand from the beach, with coarse bioclasts (shells $>1 \mathrm{~mm}$ ).

A marine gravel was found at $1.8 \mathrm{~m}$ above sea level (a.s.1.) on a rocky platform $8 \mathrm{~km}$ west of Panimbang (UTM 48S, 581039/9279586). The platform is made of siltstone (greyish volcanic ash) eroded by the overlying gravel. Rip-up clasts of siltstone are numerous at the base of the gravel, which contains many kinds of coral and shells. The thickness and clast size of the gravel decrease landward from $1 \mathrm{~m}$ thick at the rocky point to less than $10 \mathrm{~cm}$ inland (3.5 $\mathrm{m}$ a.s.1.) where the gravel turns to coarse bioclastic sand. It is, however, difficult to conclusively prove the presence of 1883 volcanic products in these deposits because older greyish ash from the underlying platform is abundant.
Anyer

The 1883 tsunami deposits around Anyer's lighthouse were briefly described by Ongkosongo (1983) and Bronto (1990). The typical sequence displays a basal unit of coarse sand with pumices (70-80\%), fresh crystals (10-15\%), coarse bioclasts (10-15\%) and lithics (5-10\%), lying directly on the substratum (calcirudite and coral platform). This coarse sand unit is yellowish at the base and brownish at the top. A horizon of angular blocks occurs in the middle part (Fig. 5a). The second unit is a light-grey coarse sand enriched in very fine white ash, rounded pumice lapilli and wood. It is $\sim 10 \mathrm{~cm}$ thick (at a depth of 20-30 cm) and its upper part was eroded before deposition of the overlying gravel, with evidence of sand incorporation into the gravel. The top gravel unit also contains abundant juvenile grains (pumice, 70-80\%; glass shards, $5 \%$; fresh crystals, $10-15 \%$; obsidian, $<3 \%$ ), together with lithic clasts $(10 \%)$ including bricks from the lighthouse, minor bioclasts $(<5 \%)$ and charcoal $(<2 \%)$. Several types of pumice are present in this third unit (white to light grey homogenous, highly vesicular pumice, light brown to yellowish pumice, banded pumice).

Sections including deposits of the 1883 events are also preserved along the Cikoneng River and its tributaries up to 


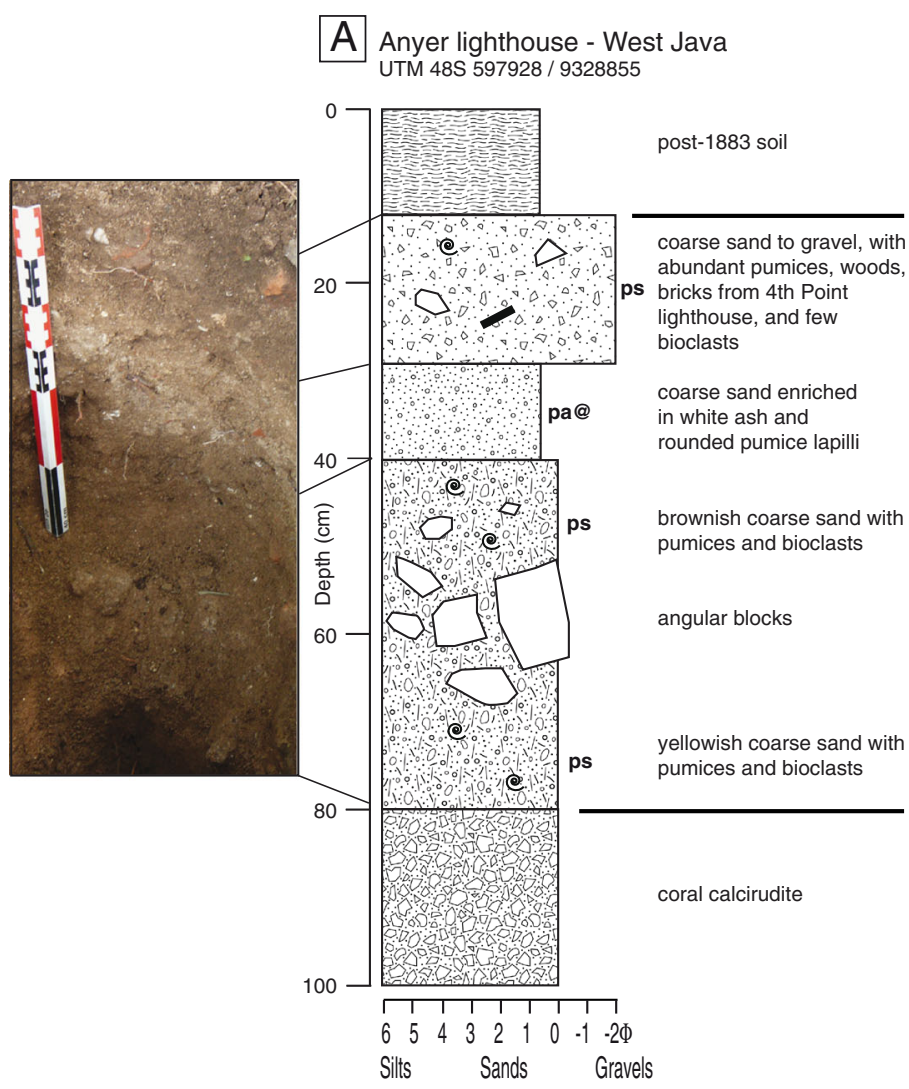

Fig. 5 Stratigraphic logs of Anyer: coastal section is located near 4th Point Java Lighthouse (at $100 \mathrm{~m}$ from the present-day shoreline), and distal section is located $3 \mathrm{~km}$ inland in a riverbed (Cikoneng). White

$4 \mathrm{~km}$ inland (Bronto 1990). In this paragraph, we describe a section located $3 \mathrm{~km}$ inland along a riverbed. The 1883 deposits overlie a soil and rounded pebbles from the riverbed (Fig. 5b). The first unit is a $\sim 20 \mathrm{~cm}$ thick sequence of crossbedded sands with $50 \%$ pumice (including pumice with veins of dense obsidian) and wood fragments. Cross-bedding indicates a current directed towards the NW. The great majority of the grains are angular to subangular and their surface is not shiny, suggesting a fluvial origin rather than marine (Cailleux and Tricart 1959). The transition from cross-stratified to laminated sands (of same composition + charcoal) marks a change in flow dynamics at $\sim 40 \mathrm{~cm}$ outcrop depth (Fig. 5b). At $-32 \mathrm{~cm}$, there is a 4-cm-thick continuous layer of white pumiceous ash and rounded lapilli. The tephra layer is eroded beneath a thick unit of laminated fine pumiceous sand $(95 \%$ varied pumices). The white, highly vesicular pumices are coarser than the other types of pumices. No marine macrofauna was detected using the binocular microscope. This is confirmed by the very low LOI at $950{ }^{\circ} \mathrm{C}(<1.3 \mathrm{wt} \%)$.

\section{Sanghyang Island}

Sanghyang Island (Fig. 1) is located in the middle of the narrowest path of the Sunda Strait, between Java and

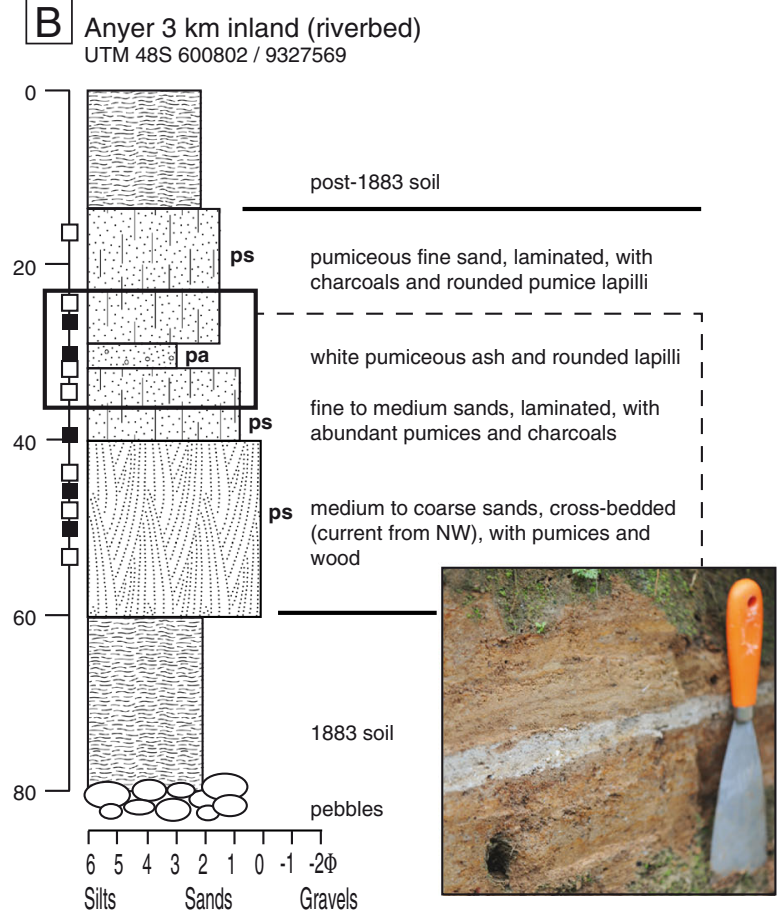

pumiceous ash of paroxysmal phase (early morning August 27) is better preserved inland (Fig. 5b) than on the coastal sections (Fig. 5a). See Fig. 2 for legend

Sumatra, $50 \mathrm{~km}$ ENE from the volcano. Coral boulders up to $4 \mathrm{~m}$ wide are dispersed in the forest and mangroves. The more complete of our sections is a $4 \mathrm{~m}$ pit at $430 \mathrm{~m}$ from the shoreline (UTM 48S, 594243/9341627), where the coral platform and bioclastic sands are covered by a 2-m-thick massive coral gravel. At $1 \mathrm{~m}$ deep, the gravel is overlain by white pumiceous fine sand mixed with coral and wood, followed by a sequence of coarse bioclastic sand with less than $20 \%$ very fine pumice. This top unit is inversely graded, from coarse sand at $-70 \mathrm{~cm}$ to gravel at $-20 \mathrm{~cm}$. We also noted that the topographic lows of the island are often filled by accumulations of rounded pumice lapilli (up to pebble size).

\section{Kalianda}

Northwest of Kalianda city (Fig. 1), traces of the 1883 eruption and tsunamis can be found everywhere around tourist resorts and mangroves up to $1 \mathrm{~km}$ inland: pumice lapilli and coral in the soil, coral gravel and bioclastic sands with pumice, glass shards and other bioclasts (shells), accumulations of pumice (usually below the coral gravel in the mangroves). These pumice deposits are up to $1 \mathrm{~m}$ thick 
and the dominant population is rounded lapilli, as on Sanghyang Island.

One of the most complete sequences along the Sumatra coast was found in a sand quarry located $3 \mathrm{~km} \mathrm{NW}$ of Kalianda city ( $250 \mathrm{~m}$ inland, $5 \mathrm{~m}$ a.s.l.). The $1883 \mathrm{se}-$ quence is up to $120 \mathrm{~cm}$ thick and cuts into paleo-dunes (Fig. 6). The first unit resembles the underlying bioclastic sand from the dune, but its composition is different since it incorporates fresh crystals and rare pumice, wood and organic matter $\left(4.7 \mathrm{wt} \%\right.$ LOI at $550{ }^{\circ} \mathrm{C}$ compared to $1.8 \mathrm{wt} \%$ in the dune). This sand is then covered by volcanic ash (greyish silty clay) which is characterised by its bimodal grain-size distribution: very fine pumices
$<100 \mu \mathrm{m}$ and subrounded pumices typically $1 \mathrm{~mm}$ in diameter. The ash is eroded beneath and reworked into another sand unit. The contact displays scour-and-fill features, plastic deformation of the ash layer into pipes and rip-up clasts in the sand. The composition of this second sand unit is close to that of the first one, with fewer bioclasts $\left(25 \mathrm{wt} \%\right.$ LOI at $950{ }^{\circ} \mathrm{C}$, compared to $35 \mathrm{wt} \%$ ), and more heavy minerals and pumice. It is draped by a thick unit of rounded pumice lapilli with charcoal and tree moulds. The uppermost dark silty sand unit is unusual: it is a mixture of very fine pumiceous ash, fresh crystals, bioclasts (coral, shells-11\% LOI at $950{ }^{\circ} \mathrm{C}$ ) and abundant fine fragments of charred wood.
Fig. 6 Stratigraphic log of Kalianda section (quarry, East Sumatra). Reworking of the greyish ash layer (at depth $90 \mathrm{~cm}$ ) by tsunami is evidenced by pipes and rip-up clasts in the pumiceous sand. See Fig. 2 for legend

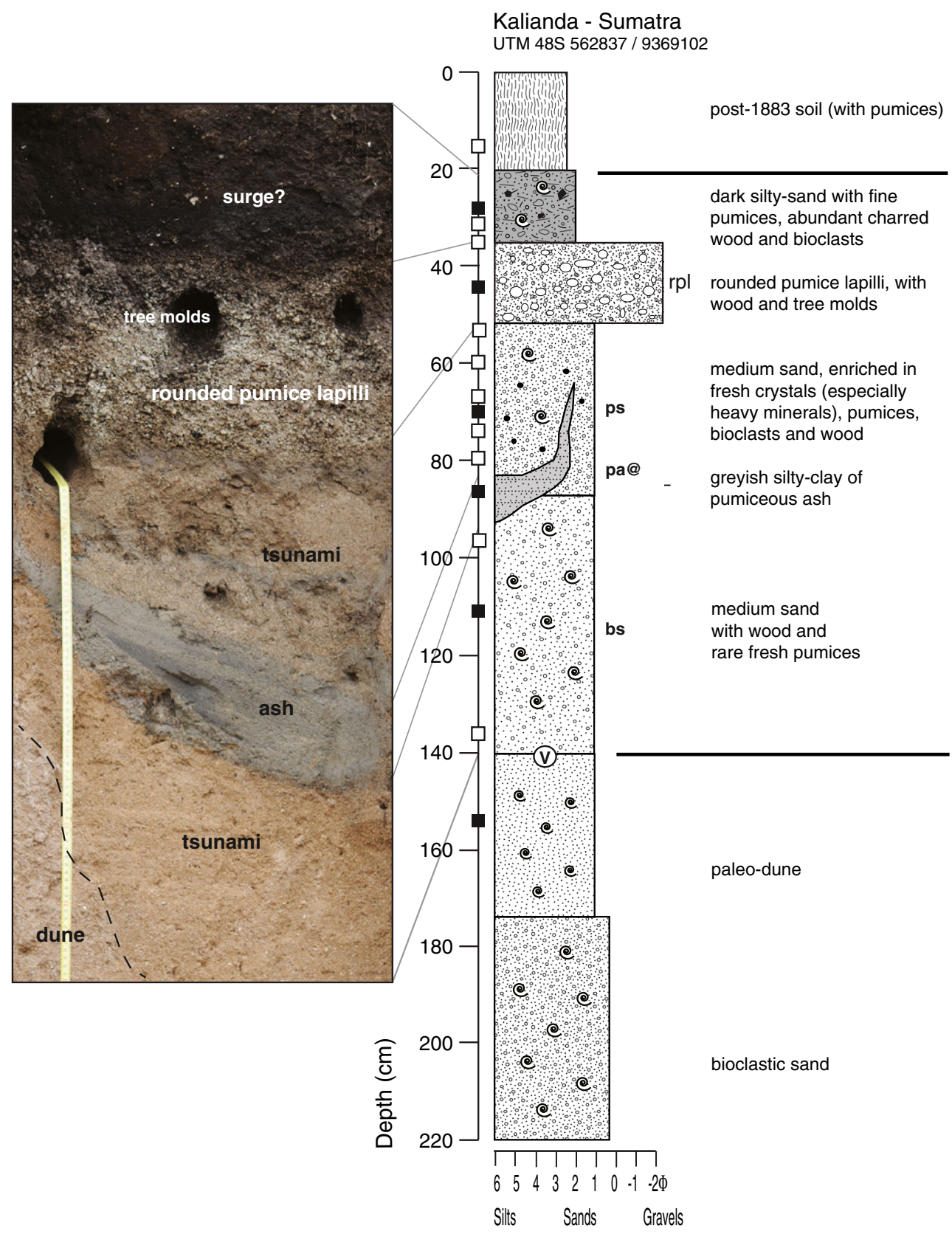

Kalianda - Sumatra

UTM 48S 562837 / 9369102 


\section{Lampong Bay}

Halfway between Kalianda and Bandar Lampung (Fig. 1), a coastal platform gently sloping landward provides good sites for preserving tsunami deposits. In the village of Gubug Garam (300 m from the present-day shoreline), the sequence is slightly different to that at Kalianda. Bioclastic sands predating the 1883 events are increasingly reworked upwards and enriched in pumice and fresh crystals (Fig. 7). The overlying pumiceous ash unit (a greyish silty clay) here incorporates lenses of rounded pumice lapilli. The upper part of the ash progressively evolves into a brown silty clay, very rich in pumices, with both terrestrial and marine bioclasts. The upper $20 \mathrm{~cm}$ of the section are reworked and thus difficult to interpret.

In this same area, many sections were accessible during the building of the Taharan PLTU power plant. The typical sequence starts with coarse bioclastic sand enriched in pumice and rip-up clasts from the underlying soil. Above is a layer of light grey primary ash (no bioclasts or wood), eroded beneath the upper pumiceous sand ( $>70 \%$ volcanic juveniles) which is normally graded. Many kinds of pumice were observed in this unit - massive, fibrous and banded, with or without veins of dense obsidian. The coarse pumices in the sand units are rounded, whereas all pumices in the ash layer are angular to sub-angular. Sand pipes extending upward from the lower

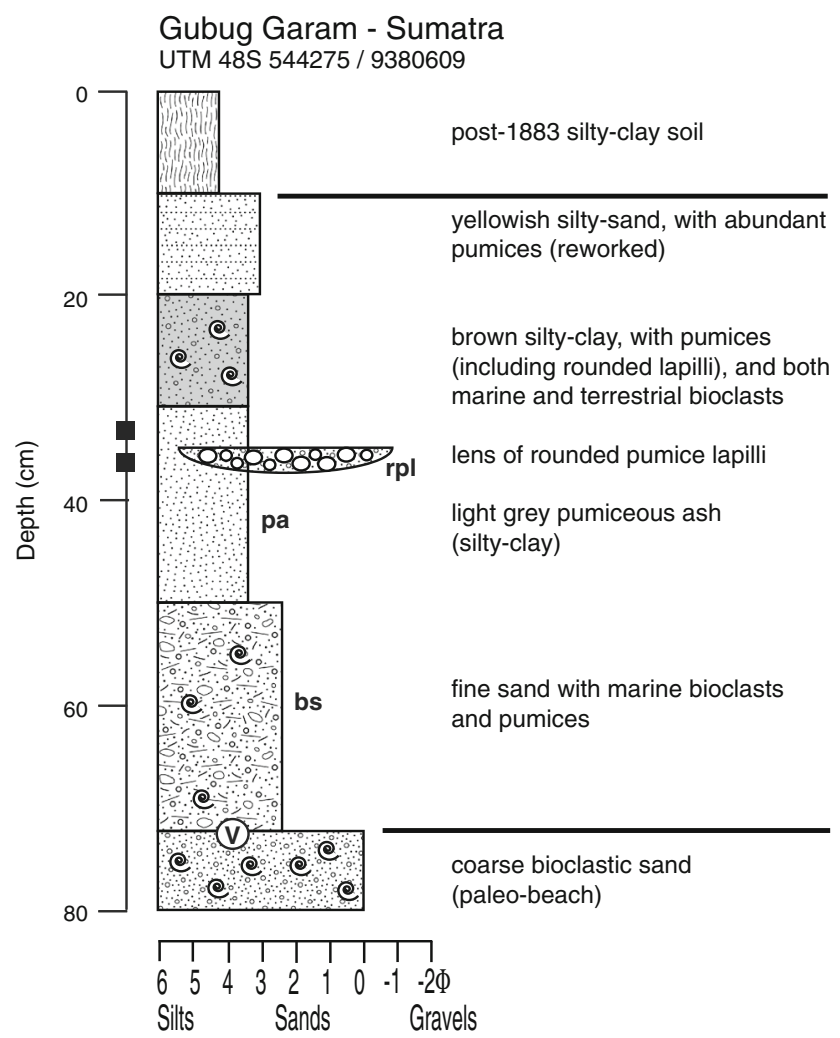

Fig. 7 Stratigraphic log of Gubug Garam section (village, Lampong Bay, East Sumatra). See Fig. 2 for legend sand unit go through the ash and up to the upper sand unit. Finally, coral boulders less than $1 \mathrm{~m}$ wide can be found on top of the sequence, buried in the soil and underlying deposits. Traces of the 1883 tsunami are limited to the coastal platform, with the deposition limit at $700 \mathrm{~m}$ inland $(<10 \mathrm{~m}$ a.s.1.), where slopes become steeper.

The most complete sequence (Fig. 8) displays more than $70 \mathrm{~cm}$ of 1883 "event deposits" above $1 \mathrm{~m}$ of lateritic soil (without any evidence of tephra or tsunamis prior to 1883). The lower half of the sequence is similar to the previous sections of the same area: (1) lower unit of coarse sand with abundant pumice, marine bioclasts and rip-up clasts from the underlying soil; (2) greyish pumiceous ash (up to lapilli size), eroded by (3) the upper pumiceous silty sand (as evidenced by rip-up clasts of greyish ash in the pumiceous sand). The upper part of the sequence displays successively (4) rounded pumice lapilli infilling the irregular surface of the upper pumiceous sand, and (5) $30 \mathrm{~cm}$ of light grey primary silt-to-sand size volcanic ash (reworked by pedogenesis only in its uppermost part). This final ash unit is organised into three subunits - a lower massive facies, an intermediate cross-bedded facies (eroding the massive facies) and an upper planar-bedded facies. Bedforms illustrated in Fig. 8 are oriented oblique to a flow coming from the South (section is oriented WSWENE).

\section{Sebesi Island}

Sebesi is located only $17 \mathrm{~km}$ North of Krakatau (Fig. 1). The island was completely devastated by pyroclastic flows and surges. Products of the 1883 climactic stage are preserved as a massive $0.5-$ to $3-\mathrm{m}$ thick unit of light grey to white pumice, with clasts ranging from fine ash to boulders up to $30 \mathrm{~cm}$, including coral blocks. A better sorted and finer basal facies can be observed at some outcrops. On the eastern shore of the island (UTM 48S, 556816/9342020), a brownish coralenriched unit is intercalated between the 1883 substratum (soil or coral breccia) and the pyroclastic flow deposits of the 1883 climactic stage. These observations are concordant with the sections described by Carey et al. (1996) on the eastern shore of Sebesi Island. The brownish coral-bearing unit has an irregular thickness (10-80 cm), a sharp basal contact, includes fragments of pumice and has a matrix that is not vesicular. Elongate clasts tend to have their long axes aligned horizontally.

Anisotropy of magnetic susceptibility

Ten samples were collected for AMS analysis in Kalianda (Fig. 9). The bioclastic sand unit (Fig. 6, depth $90-150 \mathrm{~cm}$ ) is characterised by dominant traction increasing upward (prolate ellipsoids, linear fabric) and a significant southward tilting of the $K_{\max }$ tensors (landward fabric). The pumiceous sand unit 
Fig. 8 Stratigraphic log of Lampong section (PLTU powerplant near Taharan). Photographs: rip-up clast of soil in the lower pumiceous sand (below), and bedforms in the pyroclastic surge deposits (crossbedding corresponds to oblique chute-and-pool structures attesting from an upper flow regime). See Fig. 2 for legend

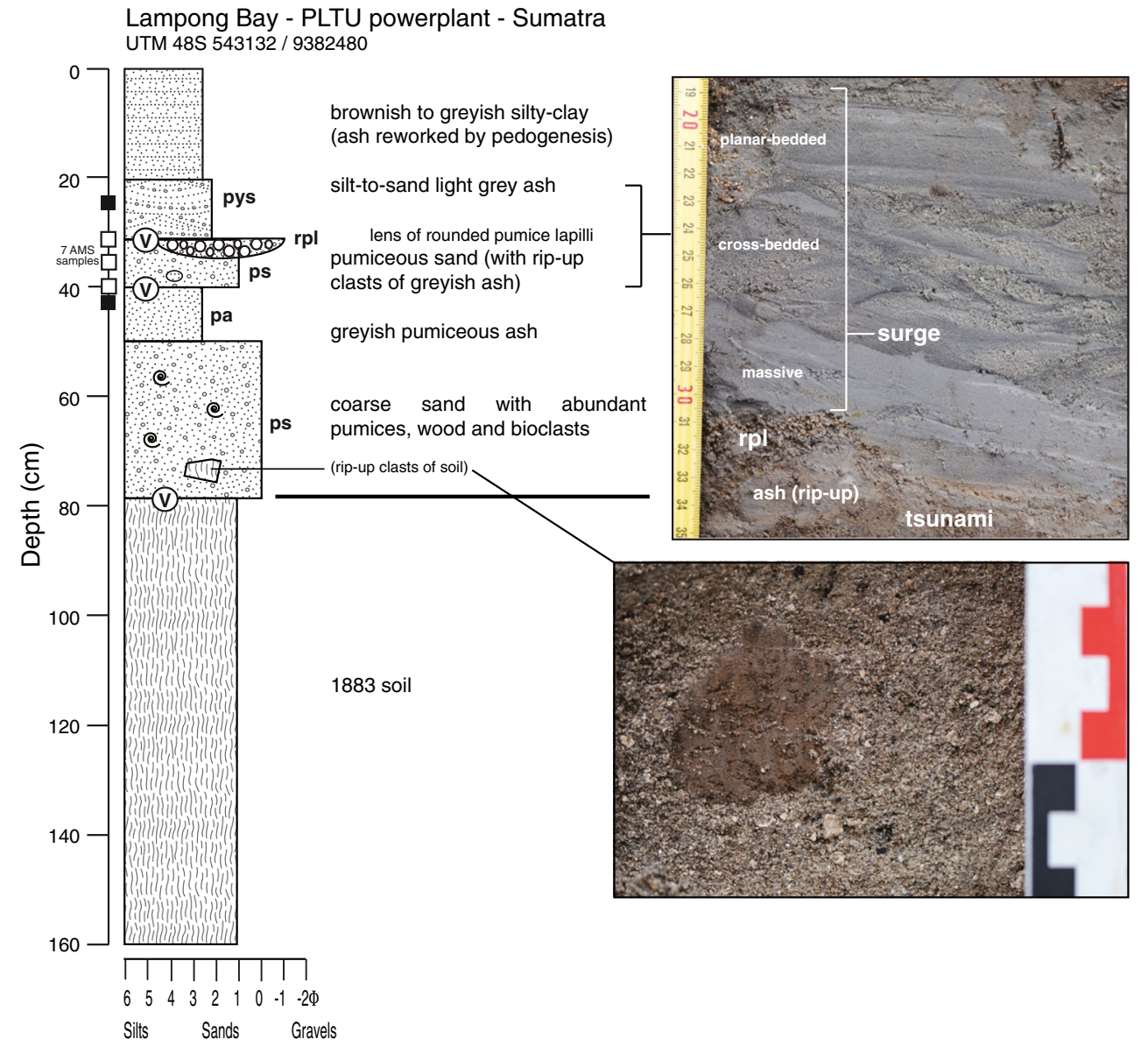

(90-50 cm) shows a succession of traction followed by settling (peak of foliation at $70 \mathrm{~cm}$ ). The uppermost dark silty sand $(35-20 \mathrm{~cm})$ has a moderate linear fabric and an oblate ellipsoid of anisotropy. Orientation of the $10 K_{\max }$ tensors is concordant with a flow oriented S-N to SSW-NNE (Fig. 10), which corresponds to the direction of Krakatau volcano.

Coastal sections in Anyer (Fig. 5a) were not sampled for AMS because of the coarse grain size of the sediments. Finer pumiceous sands in the sections found $3 \mathrm{~km}$ inland in the riverbeds (Fig. 5b) were suitable for AMS analysis. Samples of the lower cross-bedded pumiceous sand $(60-40 \mathrm{~cm})$ have $K_{\max }$ tensors oriented N-S (Fig. 10), i.e. almost perpendicular to the Krakatau direction and the present-day riverbed. This is surprising considering that the deposition was dominated by settling (oblate ellipsoids). The tsunami flow may have been initially channelled by a riverbed-oriented N-S, even if the present-day riverbed is now oriented WSW-ENE. In contrast, two samples of pumiceous sands have $K_{\max }$ tensors oriented W-E (at 15 and $34 \mathrm{~cm}$ deep). The white pumiceous ash intercalated between the pumiceous sands (Fig. 5b, depth $30 \mathrm{~cm}$ ) displays unusual AMS parameters-highly linear fabric, but oblate ellipsoids, with both lineation and foliation higher than in the under- and over-lying pumiceous sands (Fig. 9).
Three samples were collected from a bioclastic sand unit at Cidaun (Fig. 2, depth 210-156 cm). Deposition was dominated by settling ( $T>0$ and foliation $>$ lineation). Orientation and declination of the AMS tensors suggest that the lower yellowish-brown bioclastic sand $(210-180 \mathrm{~cm})$ was deposited by a flow coming from the E (Fig. 10). The upper brown silt $(180-156 \mathrm{~cm})$ has $K_{\max }$ tensors oriented successively N-S $(170 \mathrm{~cm})$ and E-W $(166 \mathrm{~cm})$. These variations likely reflect the influence of coastal morphology (V-shaped bays, islands) on flow direction.

In Lampong (Fig. 8), seven samples of the upper pumiceous sand (Fig. 8, depth 28-40 cm) were analysed for AMS, thus giving the opportunity to assess vertical variations of sediment fabrics and depositional processes in a single unit. The lower pumiceous sand $(80-50 \mathrm{~cm})$ is coarser and thus not suitable for this kind of sampling. Vertical variations of grain size in the upper pumiceous sand suggest a single phase of

Fig. 9 AMS parameters of the 1883 Krakatau tsunami deposits in Lampong (Fig. 8), Kalianda (Fig. 6) and Cikoneng (Fig. 5b). The shape parameter describes the geometry of the AMS ellipsoid, which is oblate for $T>0$ (settling mode, dominant foliation) or prolate for $T<0$ (traction mode, dominant lineation). The alignment parameter represents the development of a linear fabric and thus increases with bottom current strength 

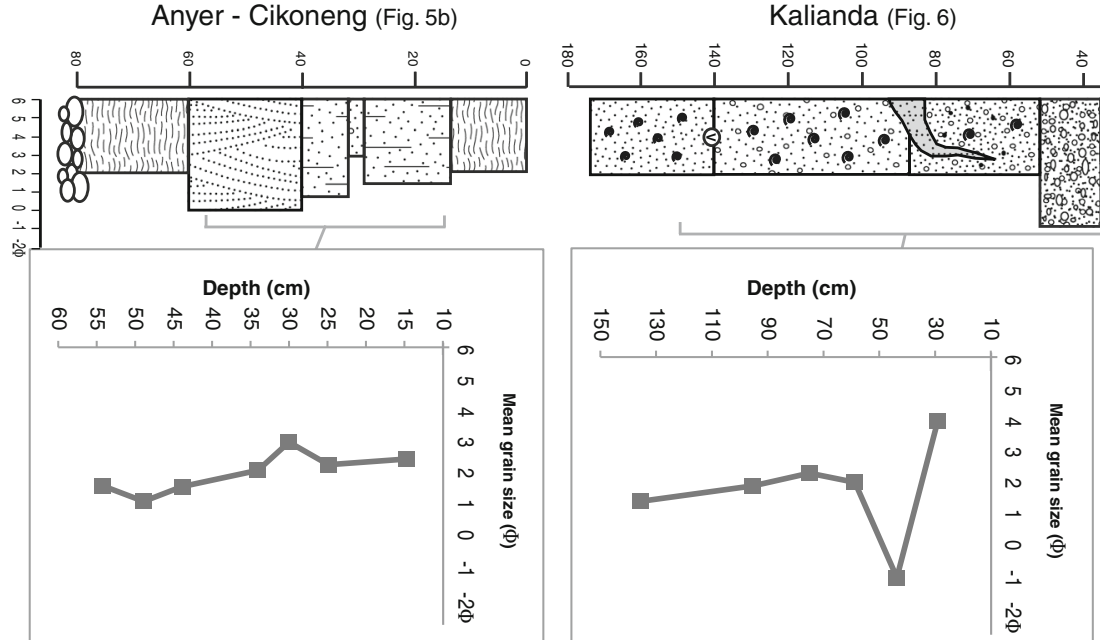

Lampong (Fig. 8)
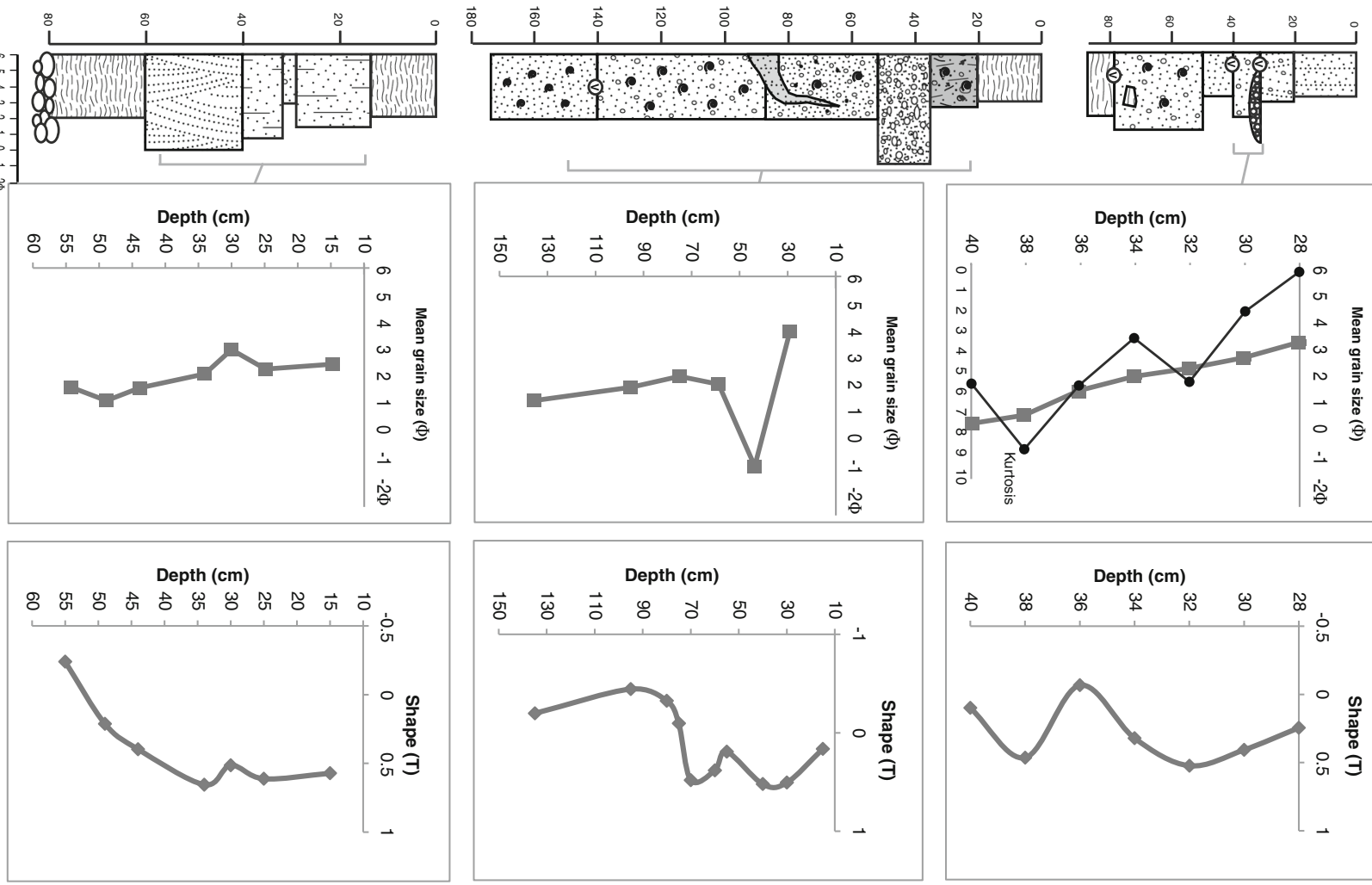

Depth (cm)
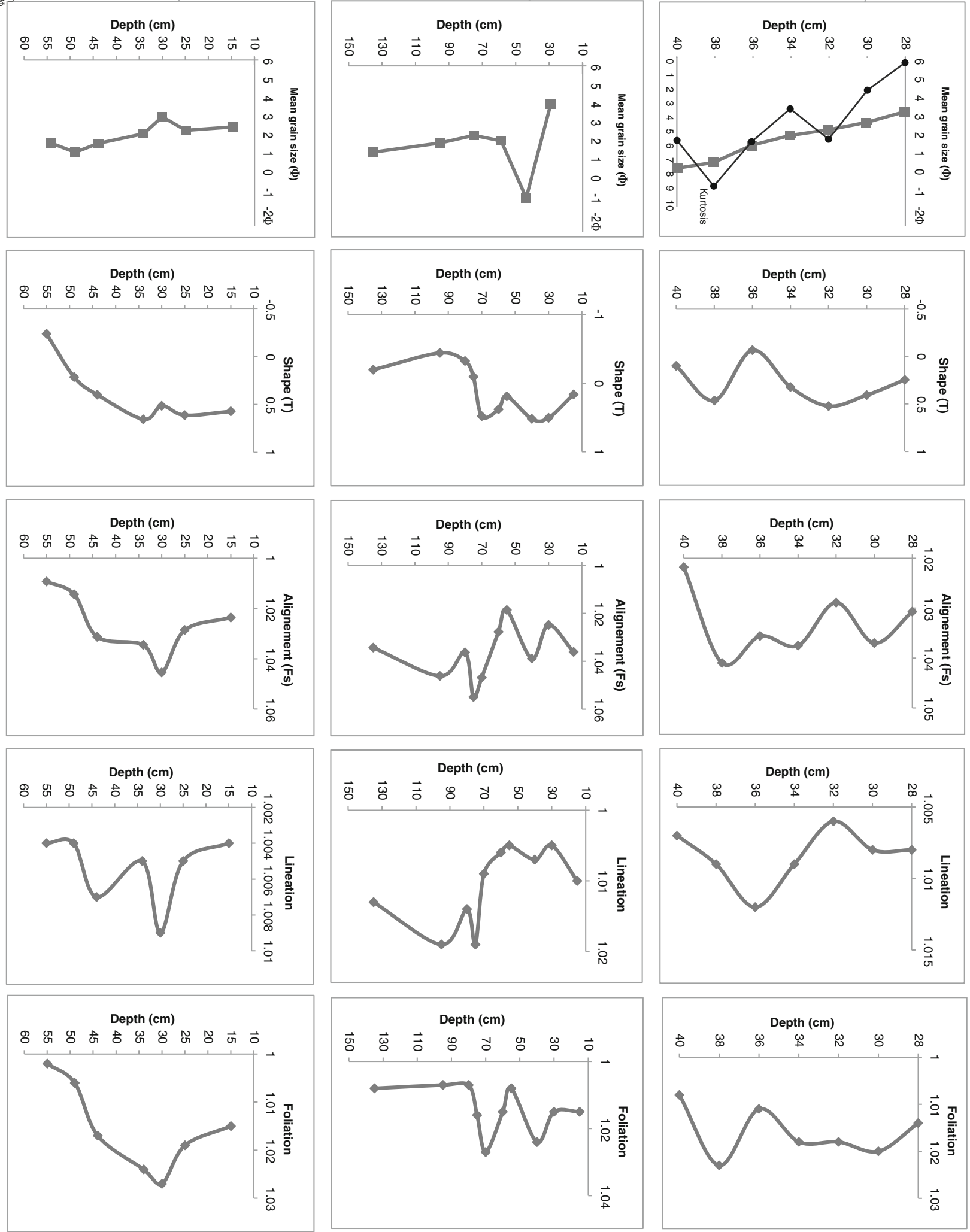
Fig. 10 Projections of AMS (anisotropy of magnetic susceptibility) maximum tensor axes $\left(K_{\max }\right)$ onto a diagram of the lower hemisphere equal areas. Dashed lines in the diagrams indicate direction of Krakatau volcano from sampling site

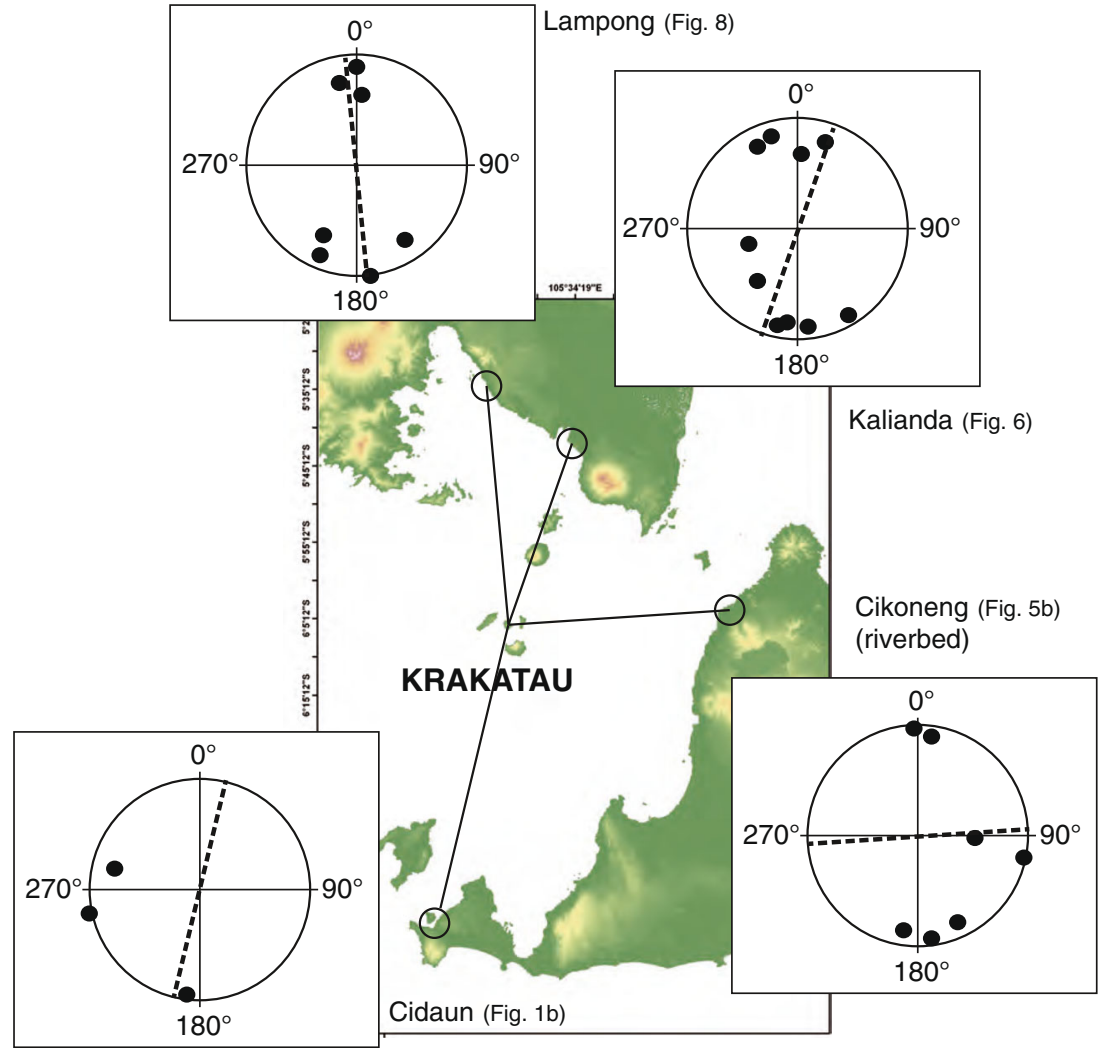

settling, characterised by normal grading and upward sorting from base to top of the unit (Fig. 9), but AMS parameters reveal changes in flow dynamics, which were not detectable in the field. Six of the seven ellipsoids are oblate, thus confirming that settling was the dominant mode (Fig. 9). Traction dominates for one sample (at $38 \mathrm{~cm}$ deep, peak of alignment parameter and lineation), but the prolate shape of the ellipsoid is not pronounced. The vertical variations of the alignment parameter display three peaks of increased linear fabric. The orientations of the maximum tensor axes $\left(K_{\max }\right)$ range from SSW-NNE to SSE-NNW, alternately tilting southward and northward (Fig. 10), thus suggesting an oscillatory flow. This area is characterised by a narrow coastal plain which slopes gently seawards and is delimited by steep slopes to the north, thus limiting tsunami propagation inland and generating turnaround periods (e.g. Dawson 1996). Similar flow behaviour was described by Paris et al. (2007) for the 2004 Indian Ocean tsunami in a similar topographic setting.

\section{Major element composition}

From the stratigraphic logs presented above, observations using a binocular microscope and major element compositions (ESM 1), we can distinguish several sedimentary and volcanic facies: primary pyroclastic deposits (pumiceous ash and lapilli), rounded pumice lapilli, bioclastic sands, quartzdominated sands and pumiceous sands.
Quartz-dominated sands (70-80 wt $\% \mathrm{SiO}_{2},<10 \mathrm{wt} \% \mathrm{CaO}$ ) were found only in Ujung Kulon (Java). Bioclastic sands contain $>40 \mathrm{wt} \% \mathrm{CaO}$ and $<40 \mathrm{wt} \% \mathrm{SiO}_{2}$, whereas the pumiceous sands have $40-60 \mathrm{wt} \% \mathrm{SiO}_{2}$ and $<30 \mathrm{wt} \%$ of $\mathrm{CaO}$ (Fig. 11). These proportions agree with the binocular microscope observations and LOI at $950{ }^{\circ} \mathrm{C}$. Bioclastic sands have up to $50 \%$ bioclasts and $35 \mathrm{wt} \%$ LOI at $950{ }^{\circ} \mathrm{C}$. Pumiceous sands have $<20 \%$ bioclasts and $<25 \mathrm{wt} \%$ LOI at $950{ }^{\circ} \mathrm{C}$, but $>50 \%$ juvenile clasts (pumiceous ash, fresh

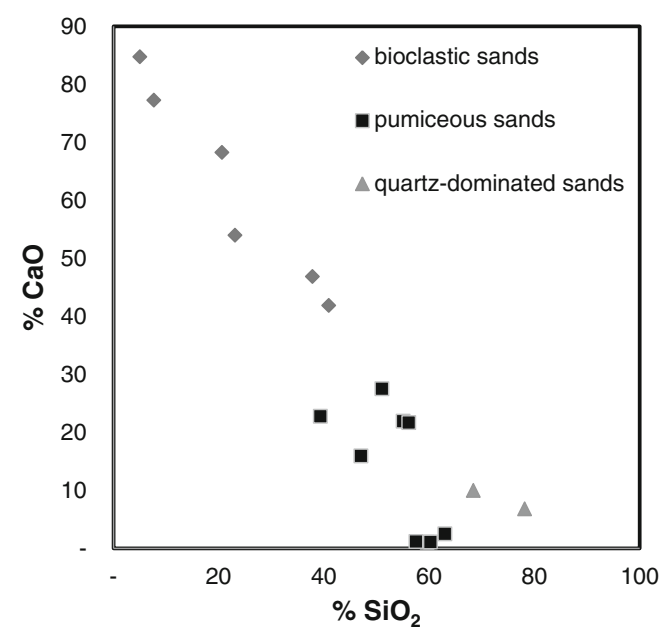

Fig. 11 Major element variation diagram for $\mathrm{SiO}_{2}$ versus $\mathrm{CaO}$ for 1883 Krakatau tsunami deposits. Values recalculated to volatile-free oxide totals of $100 \mathrm{wt} \%$ 
crystals, glass shards). Proportions of other major elements mostly depend on the variable incorporation of volcanic juvenile material, local sedimentary setting (e.g. $\mathrm{TiO}_{2}, \mathrm{Al}_{2} \mathrm{O}_{3}$, $\mathrm{MnO}$ ), and post-1883 weathering and leaching of the deposits $\left(\mathrm{Fe}_{2} \mathrm{O}_{3}, \mathrm{NaO}, \mathrm{K}_{2} \mathrm{O}\right)$. Strontium mainly originates from marine calcic biota (e.g. Chagué-Goff 2010) and is therefore higher in bioclastic sands. Barium content is generally higher in the 1883 primary pyroclastic deposits and pumiceous sands than in bioclastic sands.

Major element composition of the pumiceous sand (ESM 1) is transitional between the bioclastic sands and the 1883 pyroclastic deposits identified along the different sections (ESM 2). Comparison with samples collected near Krakatau volcano (Mandeville et al. 1996a and this study) confirms that the distal pyroclastic deposits described in this paper were clearly produced by the 1883 eruption of Krakatau volcano (ESM 2). Figure 12 shows that they differ from pumice fall deposits and ignimbrites of Rajabasa volcano (Eastern Sumatra) and Danau caldera (Western Java), two major sources of pumice in the region. The presence of andesite lithics in some pumiceous ash units is confirmed by higher $\mathrm{Mg}$ and Ca proportions (e.g. KA1-3a; greyish pumiceous ash at a depth of $85 \mathrm{~cm}$ in Fig. 6). Post-depositional weathering is evidenced by higher $\mathrm{FeO}$ and lower alkalis (e.g. Sumur and Ujung Kulon samples). The reworking of some ash fall deposits by tsunami waves led to the addition of biogenic $\mathrm{Ca}$ (e.g. SU5b; yellowish pumiceous ash at a depth of $50 \mathrm{~cm}$ in Fig. 3).

\section{Discussion}

Interpretation of the sedimentary and volcanic facies

\section{Pre-Plinian phase tsunami deposits: bioclastic sands and gravels}

Coral gravel and bioclastic sand facies (Table 1) are found in the lower part of many sections (e.g. Ujung Kulon, Sumur and Kalianda, Figs. 2, 3 and 6). These deposits resemble many tsunami deposits described in the literature (e.g. Goff et al. 2012; Cuven et al. 2013): basal erosional features and rip-up clasts from the substratum (soil), all size fractions (from very fine sands to plurimetric boulders) present in some samples, poor sorting, lateral and longitudinal variations of thickness and internal organisation, both uniform and laminated facies, units enriched in heavy minerals and numerous marine bioclasts (up to $50 \%$ of the clasts and $35 \mathrm{wt} \%$ LOI at $950{ }^{\circ} \mathrm{C}$ ). Landward thinning and fining is often reported for tsunami deposits, but this is far from systematic for the 1883 tsunami deposits. However, poor preservation of the 1883 deposits does not allow longitudinal trends to be correctly evaluated, either in terms of thickness or grain size.
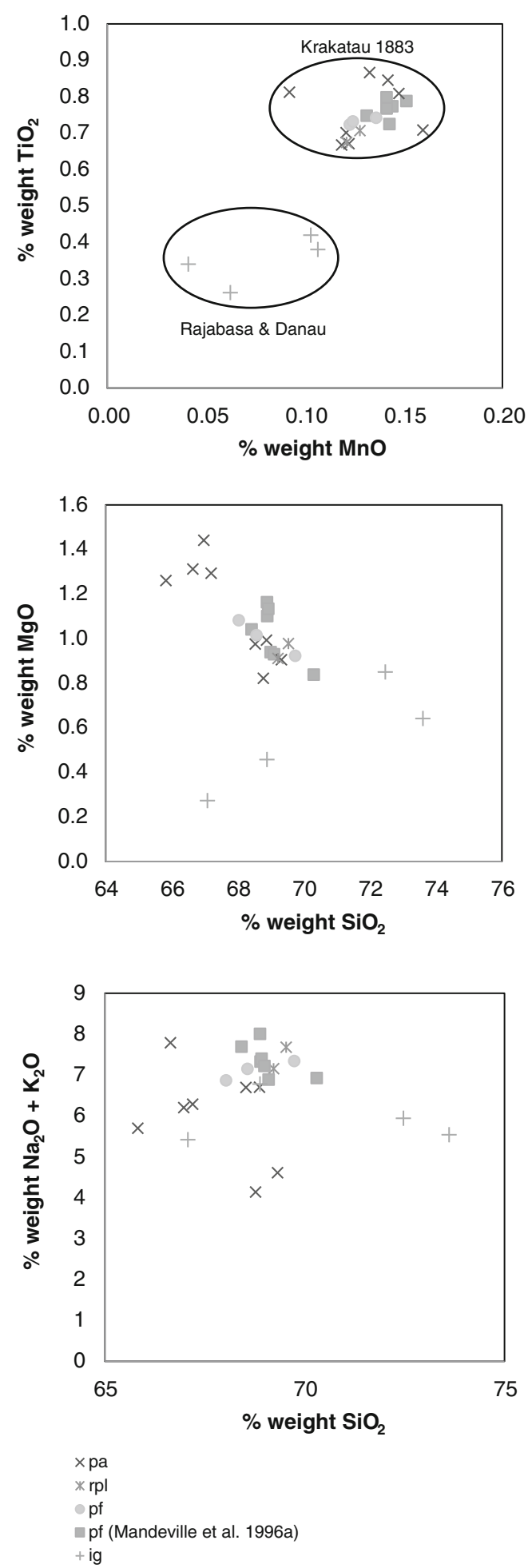

Fig. 12 Major-element variation diagrams for a $\mathrm{SiO}_{2}$ versus alkalis $\left(\mathrm{NaO}+\mathrm{K}_{2} \mathrm{O}\right)$, b $\mathrm{SiO}_{2}$ versus $\mathrm{MgO}$ and $\mathbf{c} \mathrm{MnO}$ versus $\mathrm{TiO}_{2}$. Values recalculated to volatile-free oxide totals of $100 \mathrm{wt} \%$. Sample codes: $p a$ are pumiceous ash interbedded with 1883 tsunami deposits, $r p l$ are rounded pumice lapilli (1883 tsunami deposits), $p f$ are 1883 pyroclastic flow deposits sampled in Panjang and Rakata islands (including samples from Mandeville et al. 1996a), ig are ignimbrites from Rajabasa volcano (East Sumatra) and Danau caldera (West Java) 
Table 1 Characteristics of the sedimentary facies associated with the 1883 Krakatau eruption and tsunamis along the coasts of the Sunda Strait (Indonesia)

\begin{tabular}{|c|c|c|c|c|c|}
\hline & Bioclastic sand & Pumiceous sand & Pumiceous ash & Cross-bedded ash & Rounded pumice lapilli \\
\hline Thickness (cm) & $10-50$ & $10-40$ & $5-20$ & $10-15$ & $5-20$ \\
\hline Grain size & Fine sand to gravel & Silt to coarse sand & Ash, lapilli, rare bombs & Ash (silt to sand) & Lapilli \\
\hline Bedding & Massive & Massive, laminated & Massive & Massive and cross & Massive \\
\hline Sorting & Poor to very poor & Poor to moderate & Well sorted & Moderate & Moderate \\
\hline Fabric & Clast supported & Clast or matrix supported & Matrix supported & Matrix supported & Clast supported \\
\hline Volcanic juveniles (\%) & $<40$ & $50-90$ & 100 & 100 & 100 \\
\hline Bioclasts (\%) & $<50$ & $<20$ & 0 & 0 & 0 \\
\hline $\mathrm{wt} \%$ LOI $950{ }^{\circ} \mathrm{C}$ & $<35$ & $<25$ & $<1$ & 0 & 0 \\
\hline $\mathrm{wt} \%$ LOI $550^{\circ} \mathrm{C}$ & $2-6$ & $3-6$ & $3-5$ & $<4$ & $<3$ \\
\hline Sample code & bs & ps & pa & pys & $\mathrm{rpl}$ \\
\hline Location & Java, Sumatra & Java, Sumatra & Java, Sumatra & Sumatra only & Sumatra only \\
\hline Interpretation & Tsunami (post-paroxysm) & Tsunami (Plinian paroxysm) & Ash fall & Pyroclastic surge & Tsunami backwash \\
\hline
\end{tabular}

Compared to other coastal sediments (beach, dune sands) predating the 1883 eruption, tsunami bioclastic sands are enriched in heavy minerals (Ujung Kulon, Cidaun) and organic matter (e.g. pre-tsunami dune sand in Kalianda has a LOI at $550{ }^{\circ} \mathrm{C}$ of $<2 \mathrm{wt} \%$, and overlying tsunami sand $4.7 \mathrm{wt} \%$, typically $2-6 \mathrm{wt} \%$ for tsunami deposits).

The proportion of juvenile clasts (pumices, fresh crystals) from the 1883 eruption ranges between 0 and $40 \%$ in the bioclastic sand facies, which is interpreted as being the result of tsunami waves reaching the coasts of Java and Sumatra before the onset of ash falls related to the 26-27 August Plinian phase. Eruption-tsunami deposits that lack or are poor in juvenile grains have previously been described in Japan and Turkey. Nishimura and Miyaji (1995) found sand and gravel beneath fine ash (blast) and massive pumice (Plinian fall) deposits from the AD 1640 eruption of Komagatake volcano (southern Hokkaido). The sand unit is characterised by landward thinning and fining and overlies a clearly eroded underlying soil. Minoura et al. (2000) described a tsunami deposit on the Aegean coast of Turkey without juvenile material, and overlain by felsic ash fall deposits from the Minoan eruption of Santorini, although this interpretation remains controversial (e.g. Sewell 2001).

\section{Pyroclastic fall deposits: pumiceous ash}

The 1883 pyroclastic fall deposits are preserved as pumiceous ash interbedded between tsunami deposits everywhere around Sunda Strait. Their thickness is usually less than $10 \mathrm{~cm}$ and their colour varies from yellowish to greyish, light grey or white. The dominant grain size is ash, but lapilli are quite common and there are, rarely, bombs (e.g. Sumur).

However, the apparent pyroclastic fall deposits are not always primary, and we found evidence of reworking by later tsunami waves - presence of marine bioclasts (e.g. Sumur:
$1 \mathrm{wt} \%$ LOI at $950{ }^{\circ} \mathrm{C}$ ), abundance of non-volcanic material (e.g. Anyer) and lenses of rounded pumice lapilli in volcanic ash layers (e.g. Gubug Garam) (see discussion below on the interpretation of rounded pumice lapilli). Rip-up clasts of the underlying greyish ash were found in pumiceous tsunami sands at a depth of $38 \mathrm{~cm}$ in Lampong (Fig. 8). In Kalianda, pipes and slabs of greyish ash are incorporated into the overlying tsunami sand (Fig. 6). The ash deposit was thus muddy (wet) when the tsunami came. This can be explained by the intense rain falls reported by Verbeek (1886) in this area during the night of 26-27 August.

Due to this reworking, it is not possible to reconstruct isopachs of the 1883 pyroclastic falls in Java and Sumatra from the deposits alone. Nevertheless, the thicknesses measured along the sections broadly correspond to those reported or measured by Verbeek (1886) - 4-6 cm in Anyer (see Figs. 1 and 5b, depth $28-31 \mathrm{~cm}$ for a comparison), $2 \mathrm{~cm}$ in Sumur and Ujung Kulon (Fig. 2a, depth $20-23 \mathrm{~cm}$ ), $16 \mathrm{~cm}$ in Kalianda (Fig. 6, depth $80-88 \mathrm{~cm}$ ) and $20 \mathrm{~cm}$ in Lampong Bay (Fig. 7, depth 32-50 cm; Fig. 8, depth 40-50 cm).

\section{Plinian phase tsunami deposits: pumiceous sands}

Following the increasing intensity of pyroclastic falls in the late afternoon of 26 August and night of 26-27 August, the proportion of juvenile clasts increases from the base to the top of the sections, and tsunami deposits in the upper part of the sections are characterised by their pumiceous texture (e.g. Cidaun; Fig. 2). These deposits, named pumiceous sands, present many of the diagnostic criteria of tsunami deposits (e.g. rip-up clasts of underlying ash fall deposits), but their proportion of fine pumiceous ash and lapilli is higher than $50 \%$, reaching up to $90 \%$. In the stratigraphy, pumiceous sands overlie pyroclastic fall deposits (Figs. 2, 3, 5, 6 and 8). The abundance of pumices in the tsunami pumiceous sand is 
the result of bulking through incorporation of freshly deposited pyroclastic fall deposits into the tsunami flow.

Pumiceous sands are a diagnostic facies of volcanic tsunamis. Waythomas and Neal (1998) described ash fall deposits from the Aniakchak caldera-forming eruption (ca. $3.5 \mathrm{ka}$ ) reworked into overlying tsunami pumiceous sands. The most recent example was the 1994 Rabaul eruption (Papua New Guinea), during which tsunamis were generated by pyroclastic flows (Blong and McKee 1995), and where up to three pumiceous sand units are interbedded with primary volcanic deposits (pumiceous ash and lapilli fall, surge deposits; Nishimura et al. 2005).

Bioclasts are less abundant in the pumiceous sand facies $\left(<20 \%\right.$ clasts, $<25 \%$ LOI at $\left.950{ }^{\circ} \mathrm{C}\right)$ than in the bioclastic sand facies. The source of marine bioclasts available offshore is progressively reduced by successive tsunamis. For instance, the lower bioclastic sand (Fig. 5a, depth 40-80 cm) and upper pumiceous sand in Anyer (depth 12-29 cm) have 15 and $<5 \%$ bioclasts, respectively. Nevertheless, we do not always observe this upward decrease. In Ujung Kulon, the abundance of bioclasts displays few variations from base to top of the sections: 6-12\% LOI at $950{ }^{\circ} \mathrm{C}$ in the bioclastic sands (Fig. 2a, depth $23-45 \mathrm{~cm}$ ), $13 \%$ in the pumiceous sand (depth $12-20 \mathrm{~cm})$.

\section{Pumice fall deposits reworked by tsunami: rounded pumice lapilli}

The rounded pumice lapilli described on the Sumatra coast (this study) and by Carey et al. (2001) on Sebesi Island are better sorted than pyroclastic flow deposits in Rakata, Sertung (proximal facies) and Sebesi (20 km from Krakatau volcano), and coarser-grained than the pyroclastic deposits in Sebesi (Fig. 13). Thus, rounded lapilli are not the distal complement of proximal pyroclastic flow deposits. At all sites, the rounded pumice lapilli are depleted in crystals and lithic fragments, thus ruling out pyroclastic falls and surges as depositional mechanisms. Carey et al. (2001) concluded that these rounded pumice lapilli were originally deposited on the sea surface during fallout, thus forming pumice rafts, then abraded (rounded) during tsunami runup, and finally left inland during tsunami backwash (return flow). In terms of stratigraphy, the rounded pumice lapilli consist of a 20-cm-thick unit above pumiceous tsunami sand at Kalianda (Fig. 6). They were thus deposited during the Plinian phase of the eruption. At the Lampong sections, they are found as a discontinuous layer on top of pumiceous tsunami sand and below surge deposits (Fig. 8, depth $30 \mathrm{~cm}$ ). The surge reached the coast of Sumatra at 10:30 AM of 27 August, just after the largest 10:00 AM explosion (Carey et al. 1996). At Gubug Garam, the rounded pumice lapilli appear as a small lens penetrating a pumiceous ash fall unit (Fig. 7). In Sebesi Island, Carey et al. (1996, 2001) mentioned the rounded pumice lapilli intercalated between greyish ash units interpreted as pyroclastic flow and surge deposits. The rounded pumice lapilli sampled along the coasts of Sumatra are finer grained than the ones studied by Carey et al. (1996, 2001) at Sebesi Island (Fig. 13).

Floating pumice rafts and deposits of rounded pumice lapilli were described by Blong and McKee (1995) and Nishimura et al. (2005) during the 1994 Rabaul eruption and related tsunamis (Papua New Guinea). On the north-eastern coast of New Zealand, tsunami washover lobes are associated with rounded pumice lapilli (de Lange and Moon 2007). Freundt et al. (2007) mentioned pumice lenses in a tsunami sand sheet between two pyroclastic flows of the Mateare Holocene eruption (Lake Managua, Nicaragua).

\section{Pyroclastic surge deposits}

The 1883 tsunami deposits frequently contain wood fragments (small branches, bark, leaves and roots). In some units, wood was charred and now preserved as charcoal, both in Java and Sumatra. It can be found in the bioclastic sand facies (e.g. PLTU Lampong), pumiceous sand facies (e.g. Anyer) and rounded pumice lapilli (e.g. Kalianda). Two hypotheses may explain the presence of charred wood in the 1883 deposits: (1) wood previously charred (for instance by anthropic activities) and then transported by the tsunami and (2) pyroclastic surges instantaneously charring vegetation on Sumatra and Java coasts.

There is strong evidence that surges travelled distances of up to $65 \mathrm{~km}$ and reached the southern coast of Sumatra at 10:30 AM, 30 min after the culminating 10:00 AM explosion of 27 August (Fig. 1): hundreds of people were burnt and 1,000 people were killed in the Ketimbang district, people on ships described "hot sulphurous winds" or "hurricane winds" followed by violent mud rains (Verbeek 1886). Survivors in Teluk Betung (now Bandar Lampung) also mentioned violent winds. There is no description or geological evidence of surge on the coasts of Java, but "hurricane winds" were felt aboard the W.H. Besse north of Merak (Java Sea, at $80 \mathrm{~km}$ from Krakatau). Mandeville et al. (1994) estimated the emplacement temperature of submarine pyroclastic flows to range between 350 and $550{ }^{\circ} \mathrm{C}$ (using partial thermoremanent magnetization) at distances up to $15 \mathrm{~km}$ north of from the volcano. The temperature of the flow travelling over the sea was still hot enough to char wood on Sumatra coasts, but not marine shells and coral, yielding a maximum temperature of $200{ }^{\circ} \mathrm{C}$. This is concordant with the absence of surface reflectance on charred wood sampled in Sumatra (Scott and Glasspool 2005; Hudspith et al. 2010).

The uppermost light grey ash unit found at Lampong (Fig. 8) is interpreted as a pyroclastic surge deposit. It displays the typical vertical succession of a lower massive facies to an intermediate cross-bedded facies, and an upper planar-bedded facies (e.g. Wohletz and Sheridan 1979; Fisher and 

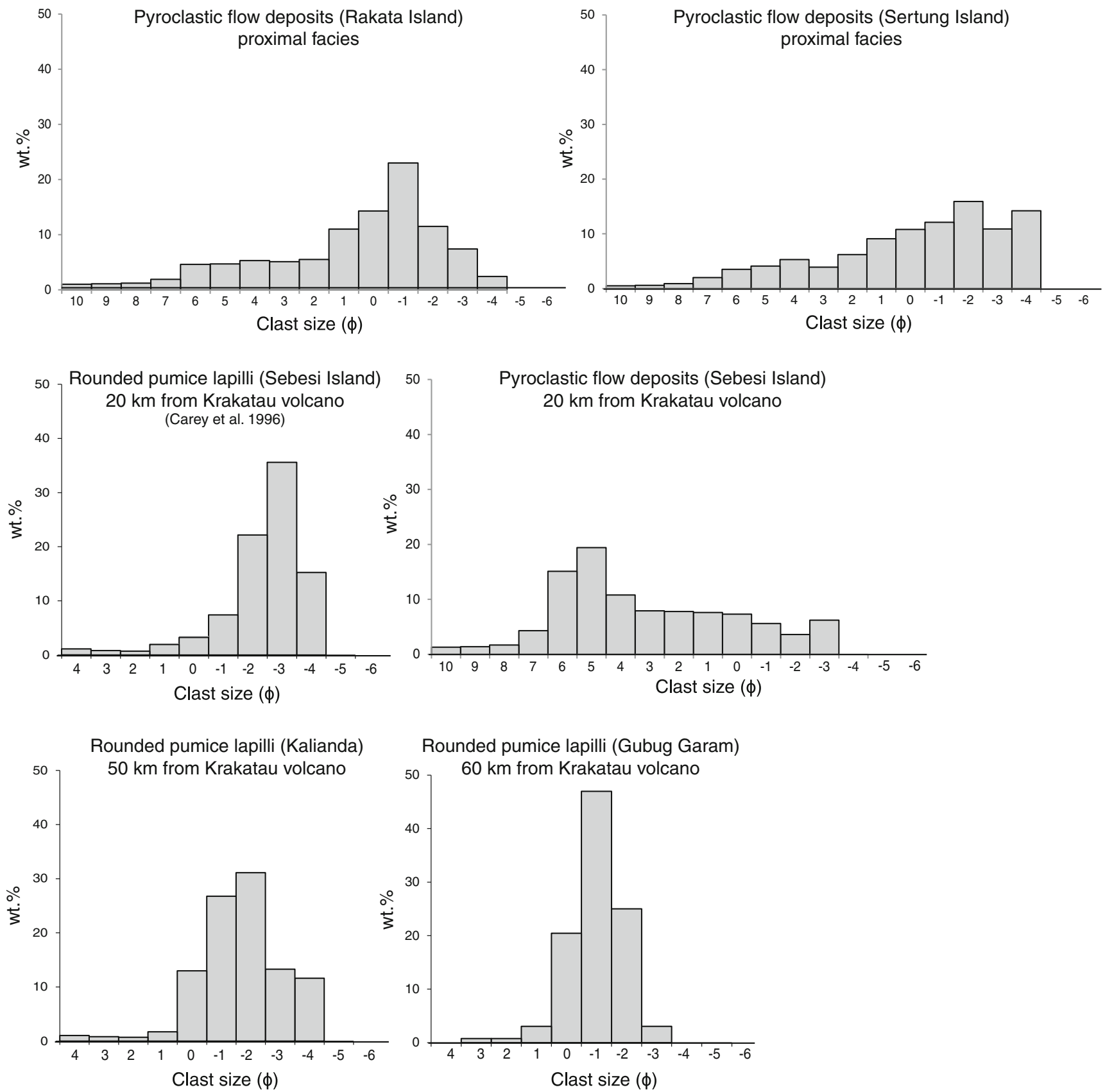

Fig. 13 Grain size distributions of pyroclastic flow deposits near the 1883 active vents (Sertung, Rakata islands) and at $50 \mathrm{~km}$ from the volcano, compared to rounded pumice lapilli at Kalianda and Lampong (Sumatra coast)

Schmincke 1984). Cross-bedding resembles the chute-andpool structures described by Schmincke et al. (1973), suggesting a supercritical flow regime, associated with grain-size sorting between sand and silt fractions of pumice. The sharp transition between the cross-bedded and the planar-bedded facies marks an abrupt decrease in flow power. Orientation of the bedforms is appropriate for a flow coming from the South. This is the first geological evidence of pyroclastic surge deposits related to the 1883 Krakatau eruption on the coasts of Sumatra. The uppermost dark silty sand found at Kalianda (Fig. 6, depth 35-20 cm) has a pumiceous ashy matrix and is very rich in charcoal. It might be considered to indicate the passage of the surge, but the abundance of marine bioclasts suggests that it is reworked.

\section{Mud rain?}

The culminating 10:00 AM explosion was followed by mud rain that lasted more than $2 \mathrm{~h}$, both in Sumatra and Java (Verbeek 1886). The uppermost units of the 1883 sequence and post- 1883 soils are usually reworked, and there is no clear evidence of the mud rain in the stratigraphic record. The 
brown silty clay overlying greyish pumiceous ash and rounded pumice lapilli at Gubug Garam (Fig. 7) contains pumices (including rounded lapilli), but also coral fragments, and both marine and terrestrial bioclasts. This unit is here inferred to represent a tsunami backwash deposit, rather than mud rain.

\section{Observations versus stratigraphy}

\section{South-western Java (Ujung Kulon, Sumur)}

In the Ujung Kulon area (Java's First Point), pumiceous ash and bombs started to fall at 6:10 PM on 26 August, followed by ash only around 7:30 PM and wet ash in the early morning of 27 August ( 4:30 AM). Ash fall deposits were found preserved in the sections we trenched in Ujung Kulon (Fig. 2a), Cidaun (Fig. 2b) and Sumur (Fig. 3). We found evidence of tsunamis below (bioclastic sand followed by pumiceous sand) and above (pumiceous sand only) the ash fall deposits, both in Ujung Kulon (Fig. 2a) and Sumur (Fig. 3). The Cidaun section suggests that at least three tsunamis reached the eastern coast of the Ujung Kulon peninsula, interbedded with ash fall deposits (Fig. 2b). The transition from bioclastic sands to pumiceous sands marks the onset of ash falls on the south-western coasts of Java (evening of 26 August). The light grey colour and high vesiculation of ash at $25 \mathrm{~cm}$ (Fig. 2a) and $140 \mathrm{~cm}$ (Fig. 2b) corresponds to the early morning of 27 August paroxysm.

According to the reports, Java's First Point was not affected by "unusual" waves before the major tsunami of 27 August at 11:00 AM, but the lighthouse was located on the southwestern side of the peninsula (Indian Ocean coast). Tsunamis were reported in Vlakke Hoek and Beneawang (western Sumatra) during the evening of 26 August and early morning of 27 August (Latter 1981).

\section{Western Java (Anyer, Sanghyang Island)}

Batavia's tide gauge (Tandjong Priok) started to record tsunami waves at 6:10 PM on 26 August, thus illustrating that a threshold was passed in the propagation of tsunamis northwards (Batavia being located $150 \mathrm{~km}$ from the volcano, on the northern coast of Java). Latter (1981) linked this first tsunami in Batavia to the 3:34 PM explosion.

Tsunamis reported in Anyer before 5:30 PM on 26 August are described as small agitations of sea level, but explosions in the evening generated 1-2 $\mathrm{m}$ high tsunamis, for example at Carita (Cyringin, $30 \mathrm{~km} \mathrm{SSW}$ of Anyer). These tsunamis are not recorded individually in the sections described, and their traces might have been eroded by subsequent tsunamis. The pumiceous sands in the lower part of the Anyer section (Fig. 5a, depth $>40 \mathrm{~cm}$ ) were most probably deposited by the early morning 27 August tsunamis, at the beginning of the climactic stage of the eruption ( 5:30 AM). In the early morning of 27 August, volcanic activity shifted from a convecting column, with localised pyroclastic flows, to a collapsing column (Self 1992). The production of largevolume pyroclastic flows resulted in an increasing amplitude of tsunami waves. According to Latter (1981), the 5:05 AM explosion generated a tsunami that propagated in all directions. Merak, Cyringin and Anyer were devastated by tsunami waves between 6:30 and 9:00 AM, leaving few survivors. Verbeek (1886) then noted a sudden increase in the intensity of ash falls at 9:30 AM in the Anyer area. The units of light grey pumiceous ash intercalated between pumiceous tsunami sands (Fig. 5a, depth 30-40 cm; Fig. 5b, depth $28-31 \mathrm{~cm}$ ) could represent this intense phase of ash falls. The culminating tsunami occurred at 10:30 in Anyer and 11:00 in Java's First Point. Waves were as high as the coconut trees in Merak, and destroyed the lighthouse at Java's 4th Point (Anyer). Bricks of the lighthouse were found in the upper pumiceous sand up to $4 \mathrm{~km}$ inland (Fig. 5a, depth 13-30 cm; Fig. 5b, depth 15$28 \mathrm{~cm})$.

A similar stratigraphy is found in Sanghyang Island, but the tsunami deposits there are less rich in pumice than in Anyer. The 10:30 AM tsunami might be attested by bioclastic sands lying on white pumiceous fine sand, and the earlier tsunamis left a 2-m-thick coral breccia (7:30 or 9:00 AM tsunamis in Merak?). The relatively low pumice abundance in the Sanghyang Island deposits is consistent with the late arrival of ash falls in the Merak area (no ash falls before 10:30 AM in Merak, based on Verbeek 1886).

\section{Eastern Sumatra (Kalianda, Lampong Bay)}

Ketimbang and Kalianda were damaged by tsunamis sooner than elsewhere in Sumatra and Java. Ketimbang was evacuated after 8:00 PM on 26 August and devastated before 6:30 AM on 27 August. Verbeek (1886) mentioned successively: ash falls with pumice bombs during the night 26-27 August, then an intense "rain" of lapilli and bombs at 9:00 10:00 AM (the possible source of the rounded pumice lapilli), a short phase of hot ash at 12:00 AM, followed by cold ash or mud rains until 28 August. This scenario agrees particularly well with the stratigraphic record in Kalianda (Fig. 6). The lower tsunami sands (depth $88-140 \mathrm{~cm}$ ) have low pumice abundance and could be the result of the tsunamis on the evening of 26 August, prior to the main ash falls (depth 70 $88 \mathrm{~cm}$ ). The upper tsunami pumiceous sand erosionally overlies the wet ash fall deposits and ends with deposits of rounded pumice lapilli (depth $35-55 \mathrm{~cm}$ ).

The most complete section trenched along the coasts of Lampong Bay (Fig. 8) displays from base to top (1) a thick pumiceous tsunami sand with rip-up clasts of the underlying soil, (2) wet ash fall deposits, (3) a second unit of pumiceous tsunami sands with rip-up clasts of ash fall deposits and lenses of pumice rounded lapilli and (4) a cross-stratified surge 
deposit. This stratigraphy can be compared with observations in Teluk Betung (Fig. 1), where the first damaging tsunami occurred at 6:30 AM (27 August). A second tsunami is reported at $\sim 7: 00 \mathrm{AM}$ in Lampong Bay (by the ship

\section{KRAKATAU}

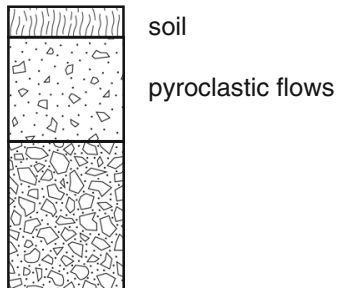

lag breccia
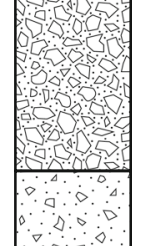

0
4
4

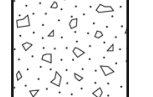

caldera collapse?

culminating explosion 10:00 AM August 27
SEBESI ISLAND

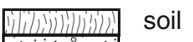

SUMATRA

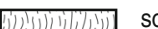

soil

soil

pys pyroclastic surge

pyroclastic flow/surge

(massive facies)

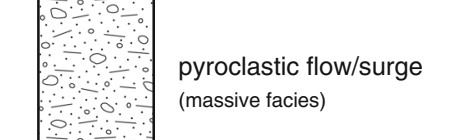

pyroclastic flow/surge

(stratified facies)

-
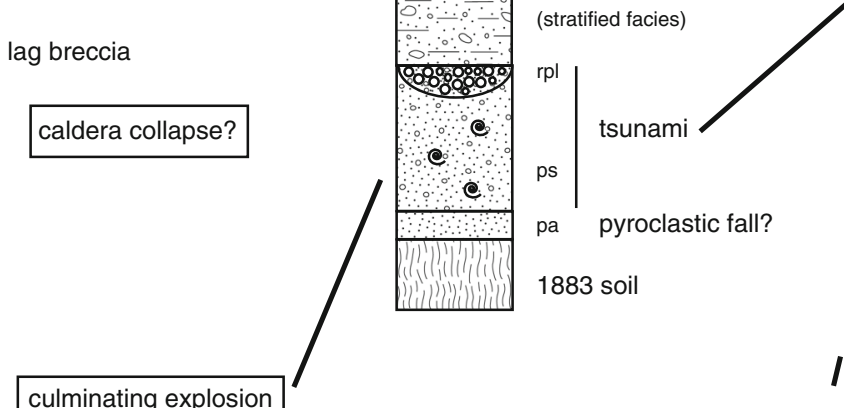

ps

pa pyroclastic fall?

1883 soil

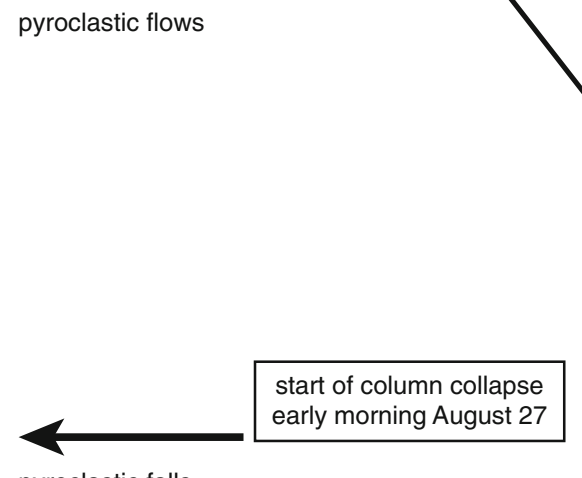

pyroclastic falls

pyroclastic surge

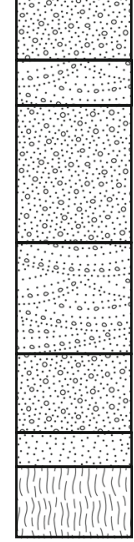

pyroclastic surge

pyroclastic falls

pyroclastic falls

pyroclastic surge

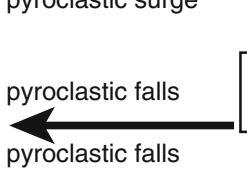

1883 soil

Fig. 14 Interpretive stratigraphic columns of 1883 Krakatau pyroclastic deposits and tsunami deposits, from the proximal zone (Panjang, Rakata and Sertung islands-Stehn 1929; Self and Rampino 1981; Mandeville et al. 1996b), to Sebesi (20 km from the volcano-Carey et al. 1996) and
Sumatra and Java coasts (40-70 km from the volcano- this study). Sedimentary and volcanic facies - $b s$ bioclastic sand, $p a$ pumiceous ash, $p s$ pumiceous sand, $r p l$ rounded pumice lapilli, $p y s$ pyroclastic surge. Not to scale 
Loudon), reaching Teluk Betung at 7:45 AM. It is impossible to state which one of these tsunamis produced the lower pumiceous sand (Fig. 8, depth $50-80 \mathrm{~cm}$ ). The intensity of ash falls increased after 7:00 AM, shifting to mud rains between 10:45 and 12:45 AM. The timing of the major tsunami following the 10:00 AM explosion is not documented in Lampong Bay, because most of the people there were killed by earlier tsunamis or evacuated to higher ground. As at Kalianda, this tsunami is evidenced by an upper unit of pumiceous sand and rounded pumice lapilli (Fig. 8, depth $30-40 \mathrm{~cm})$.

The pyroclastic surge was felt shortly after the tsunami (e.g. account by the ship Charles Bal, from near Sanghyang Island). This agrees with the stratigraphic position of the upper tsunami sand and rounded pumice lapilli under the surge deposits in Lampong (Fig. 8) and Sebesi (Carey et al. 1996). Considering that the tsunami waves reached the coasts of Sumatra and Java after 30-40 min of propagation (Verbeek 1886; Simkin and Fiske 1983), we can estimate that the surge travelled over seawater at a velocity of less than $30 \mathrm{~m} / \mathrm{s}$ (if the surge and tsunami shared the same source). The ships Loudon and Charles Bal, both located $65 \mathrm{~km}$ from the volcano, felt the effects of the surge at $\sim 10: 30 \mathrm{AM}$, yielding an average velocity of $36 \mathrm{~m} / \mathrm{s}$. Pumice rafts may have locally increased seawater viscosity and density, favouring the transport of pyroclastic surges across the sea, as suggested by Allen and Cas (2001) for the Kos Plateau Tuff across the Aegean Sea.

\section{Conclusions}

The tsunamigenic 1883 eruption of Krakatau volcano represents an emblematic case study for coupling eruptive history (through stratigraphy and observations) and the sedimentary record of tsunamis. Our sedimentological approach to the tsunami deposits interbedded with primary or reworked pyroclastic deposits demonstrates that past eruptions can be reconstructed using their tsunami record. Five kinds of sedimentary and volcanic facies were identified: (1) bioclastic sands deposited by tsunamis before the Plinian phase of the eruption, (2) pumiceous tsunami sands indicating the onset of the Plinian phase, (3) rounded pumice lapilli corresponding to pyroclastic falls reworked by tsunami (and most probably deposited by the backwash), (4) pumiceous ash fall deposits (primary or reworked) and (5) pyroclastic surge deposits overlying the uppermost tsunami deposits (only in Sumatra).

The stratigraphic record agrees quite well with the observations and allows a scenario to be reconstructed for each location. Figure 14 displays a tentative synthesis of the proximal and distal stratigraphy of the 1883 eruption and tsunamis. Links are proposed between the beginning of the Plinian phase in the late afternoon of August 26, pyroclastic fall deposits on the coasts of Java and Sumatra, and the enrichment of the tsunami deposits in pumice (pumice sand facies). Thicknesses of ash fall deposits measured along the sections are concordant with thicknesses reported by Verbeek (1886). Tsunami observed before the paroxysm (bioclastic sand facies) might have been generated by precursory pyroclastic flows or landslides of the volcanic edifice. There are no tsunamis recorded above the surge deposits in Sumatra, i.e. no tsunamis after the main explosion (10:00 AM August 27). The temperature of the flow travelling over the sea at $30-36 \mathrm{~m} / \mathrm{s}$ was still hot enough to char wood fragments (without surface reflectance), but not marine shells and corals, yielding a maximum temperature of $200{ }^{\circ} \mathrm{C}$. The final phase of the eruption and formation of the submarine caldera might have generated tsunamis, but they are not recorded along the coastal sections described here.

Volcanic tsunamis expand the potential damage area of many underwater and coastal volcanoes, and must be considered in terms of volcanic hazard assessment. Learning from past tsunamigenic eruptions helps understand the relationships between the eruptive processes, thresholds in eruptive activity and the timeframe and magnitude of tsunamis. Using current knowledge, tsunamis happening during a volcanic eruption are unpredictable, and sometimes numerous, yet volcanic monitoring is often unsuited to dealing with tsunamis.

Acknowledgements This work was funded by French ANR (Agence Nationale de la Recherche) program "Young Scientist" 2008-project VITESSS (Volcano-Induced Tsunamis: Sedimentary Signature and numerical Simulation) whose leader was Raphaël Paris. The authors are also grateful to Jean-Marc Hénot (SEM, Clermont-Ferrand), Marc Diraison and Martine Trautmann (AMS and grain size analysis, Strasbourg), Claudia Maxcia Setjaatmadja, Eko Yulianto and Brian Atwater (for giving unpublished manuscript on coral boulders), and David Dublanchet (for building the kml files). The authors thank Scott Bryan, Adam Switzer and an anonymous reviewer for their careful reviews, as well as Steve Self and James White. This is Laboratory of Excellence ClerVolc contribution $\mathrm{n}^{\circ} 90$.

\section{References}

Allen SR, Cas RAF (2001) Transport of pyroclastic flows across the sea during the explosive, rhyolitic eruption of the Kos Plateau Tuff, Greece. Bull Volcanol 62:441-456

Begét JE (2000) Volcanic tsunamis. In: Sigurdsson H, Houghton B, Mc Nutt SR, Rymer H, Stix J (eds) Encyclopedia of volcanoes. Academic Press, New York, pp 1005-1013

Blong RJ, McKee CO (1995) The Rabaul eruption 1994 - destruction of a town. Natural Hazards Research Center, Macquarie University, Australia, $52 \mathrm{p}$

Bourgeois J (2009) Geologic effects and records of tsunamis. In: Robinson AR, Bernard EN (eds.) The sea, vol. 15: tsunamis. Harvard: Harvard University Press. pp 53-91

Bronto S (1990) Gunung Krakatau, Berita Berkala Vulkanologi,. Edisi Khusus No.133, Direktorat Vulkanologi, 5h, unpublished.

Cailleux A, Tricart J (1959) Contribution à l'étude des sables et des galets. CDU, Paris, $376 \mathrm{p}$ 
Camus G, Vincent PM (1983) Discussion of a new hypothesis for the Krakatau volcanic eruption in 1883. J Volcanol Geotherm Res 19: $167-173$

Camus G, Gourgaud A, Vincent PM (1987) Petrologic evolution of Krakatau (Indonesia): implications for a future activity. J Volcanol Geotherm Res 33:299-316

Carey S, Sigurdsson H, Mandeville C, Bronto S (1996) Pyroclastic flows and surges over water: an example from the 1883 Krakatau eruption. Bull Volcanol 57:493-511

Carey S, Morelli D, Sigurdsson H, Bronto S (2001) Tsunami deposits from major explosive eruptions: an example from the 1883 eruption of Krakatau. Geology 29(4):347-350

Chagué-Goff C (2010) Chemical signature of palaeotsunamis: a forgotten proxy? Mar Geol 271:67-71

Choi BH, Pelinovsky E, Kim KO, Lee JS (2003) Simulation of the transoceanic tsunami propagation due to the 1883 Krakatau volcanic eruption. Nat Hazards Earth Syst Sci 3:321-332

Cuven S, Paris R, Falvard S, Miot-Noirault E, Benbakkar M, Schneider JL, Billy I (2013) High-resolution analysis of a tsunami deposit: case-study from the 1755 Lisbon tsunami in south-western Spain. Mar Geol 337:98-111

Dawson AG (1996) The geological significance of tsunamis. Zeitschrift für Geomorphologie Suppl Band 102:199-210

Dawson AG, Stewart I (2007) Tsunami deposits in the geological record. Sediment Geol 200:166-183

de Lange WP, Moon VG (2007) Tsunami washover deposits, Tawharanui, New Zealand. Sediment Geol 200:232-247

Ewing M, Press F (1955) Tide-gage disturbances from the great eruption of Krakatoa. Trans Am Geophys Union 36(1):53-60

Fisher RV, Schmincke HU (1984) Pyroclastic rocks. Springer, Berlin, 472 $\mathrm{p}$

Francis PW (1985) The origin of the 1883 Krakatau tsunamis. J Volcanol Geotherm Res 25:349-363

Freundt A, Strauch W, Kutterolf S, Schmincke HU (2007) Volcanogenic tsunamis in lakes: examples from Nicaragua and general implications. Pure Appl Geophys 164:527-545

Giachetti T, Paris R, Kelfoun K, Ontowirjo B (2012) Tsunami hazard related to a flank collapse of Anak Krakatau volcano, Sunda Strait, Indonesia. Geological Society, London, Special Publication 361:7989

Goff JR, Chagué-Goff C, Nichol SL, Jaffe B, Dominey-Howes D (2012) Progress in palaeotsunami research. Sediment Geol 243-244:70-88

Hudspith VA, Scott AC, Wilson CJN, Collinson ME (2010) Charring of woods by volcanic processes: an example from the Taupo ignimbrite, New Zealand. Palaeogeogr Palaeoclimatol Palaeoecol 291: 40-51

Keating BH, Helsley CE, Wanink M, Walker D (2011) Tsunami deposit research: fidelity of the tsunami record, ephemeral nature, tsunami deposits characteristics, remobilization of sediments by later waves, and boulder movement. In: Mörner NA (Ed.) The tsunami threatResearch and Technology. InTech, $714 \mathrm{p}$

Latter JN (1981) Tsunamis of volcanic origin: summary of causes with particular references to Krakatoa, 1883. Bull Volcanol 44(3):467490

Maeno F, Imamura F (2011) Tsunami generation by a rapid entrance of pyroclastic flow into the sea during the 1883 Krakatau eruption, Indonesia. J Geophys Res 116, B09205

Mandeville CW, Carey S, Sigurdsson H, King J (1994) Paleomagnetic evidence of high-temperature emplacement of the 1883 subaqueous pyroclastic flows from Krakatau volcano, Indonesia. J Geophys Res 99:9487-9504

Mandeville CW, Carey S, Sigurdsson H (1996a) Magma mixing, fractional crystallization and volatile degassing during the 1883 eruption of Krakatau volcano, Indonesia. J Volcanol Geotherm Res 74:243274
Mandeville CW, Carey S, Sigurdsson H (1996b) Sedimentology of the Krakatau 1883 submarine pyroclastic deposits. Bull Volcanol 57: $512-529$

Minoura K, Imamura F, Kuran U, Nakamura T, Papadopoulos GA, Takahashi T, Yalciner AC (2000) Discovery of Minoan tsunami deposits. Geology 28(1):59-62

Nishimura Y, Miyaji N (1995) Tsunami deposits from the 1993 Southwest Hokkaido earthquake and the 1640 Hokkaido Komagatake eruption, Northern Japan. Pure Appl Geophys 144: 719-733

Nishimura Y, Nakagawa M, Kuduon J, Wukawa J (2005) Timing and scale of tsunamis caused by the 1994 Rabaul eruption, East New Britain, Papua New Guinea. In: Satake K (ed) Tsunamis: case studies and recent developments. Springer, New York, pp 43-56

Nomanbhoy N, Satake K (1995) Generation mechanism of tsunamis from the 1883 Krakatau eruption. Geophys Res Lett 22(4):509-512

Ongkosongo OSR (1983) Coastal geomorphology of Cilegon-Labuhan, West Java, with special emphasis on the remnants of the 1883 Krakatau tsunamic activity. Symposium on 100th year Development of Krakatau and its surroundings, August 23-27, 1983, Jakarta, Indonesia

Paris R, Lavigne F, Wassmer P, Sartohadi J (2007) Coastal sedimentation associated with the December 26, 2004 in Lhok Nga, west Banda Aceh (Sumatra, Indonesia). Mar Geol 238:93-106

Paris R, Switzer AD, Belousova M, Belousov A, Ontowirjo B, Whelley PL, Ulvrova M (2013) Volcanic tsunami: a review of source mechanisms, past events and hazards in Southeast Asia (Indonesia, Philippines, Papua New Guinea). Natural Hazards. doi:10.1007/ s11069-013-0822-8

Pelinovsky E, Choi BH, Stromkov A, Didenkulova I, Kim HS (2005) Analysis of tide-gauge records of the 1883 Krakatau tsunami. In: Satake K (ed) Tsunamis: case studies and recent developments. Springer, New York, pp 57-78

Schmincke HU, Fisher RV, Waters AC (1973) Antidune and chute and pool structures in the base surge deposits of the Laacher See area, Germany. Sedimentology 20:553-574

Scott AC, Glasspool IJ (2005) Charcoal reflectance as a proxy for the emplacement temperature of pyroclastic flow deposits. Geology 33(7):589-592

Self S (1992) Krakatau revisited: the course of events and interpretation of the 1883 eruption. Geo Journal 282:109-121

Self S, Rampino MR (1981) The 1883 eruption of Krakatau. Nature 294: 699-704

Setjaatmadja CM (2007) Boulder deposition associated with the 1883 Krakatau tsunami in Java and Sumatra. Unpublished M.S. Thesis, Asian Institute of Technology, Bangkok

Sewell DA (2001) Earth, air, fire and water. An elemental analysis of the Minoan eruption of Santorini volcano in the Late Bronze Age. Unpublished PhD Thesis, University of Reading, $427 \mathrm{p}$

Simkin T, Fiske RS (1983) Krakatau 1883: the volcanic eruption and its effects. Smithsonian Institution Press, Washington DC, $464 \mathrm{p}$

Stehn CE (1929) The geology and volcanism of the Krakatau group. Proceedings of the Fourth Pacific Science Congress, Batavia, pp 155

Symons G (1888) The eruption of Krakatau and subsequent phenomena: reports of the Krakatau Committee of the Royal Society. Trubner, London

Terry JP, Lau AYA, Etienne S (2013) Reef-platform coral bouldersevidence for high-energy marine inundation events on tropical coastlines. Springer Briefs in Earth Science, 102 p

Umbgrove JHF (1947) Coral reefs of the East Indies. Bull Geol Soc Am $58: 729-778$ 
Van den Berg GD, Boer W, de Haas H, van Weering TCE, van Wijhe R (2003) Shallow marine tsunami deposits in Teluk Banten (NW Java, Indonesia), generated by the 1883 Krakatau eruption. Mar Geol 197: 13-34

Verbeek RM (1886) Krakatau. Batavia, Imprimerie de l'Etat, 567 p

Verstappen HT (1956) Landscape development of the Udjung Kulon Game Reserve. Penggemar Alam 36:37-51

Wassmer P, Schneider JL, Fonfrège AV, Lavigne F, Paris R, Gomez C (2010) Use of anisotropy of magnetic susceptibility (AMS) in the study of tsunami deposits: application to the 2004 deposits on the eastern coast of Banda Aceh, North Sumatra, Indonesia. Mar Geol 275:255-272
Waythomas CF, Neal CA (1998) Tsunami generation by pyroclastic flow during the 3500-year BP caldera-forming eruption of Aniakchak volcano, Alaska. Bull Volcanol 60:110 124

Williams H (1941) Calderas and their origin. Univ Calif Publ Geol Sci 25: 239-346

Wohletz KH, Sheridan MF (1979) A model of pyroclastic surge. Geol Soc Amer Spec Pap 180:177-193

Yokoyama I (1981) A geophysical interpretation of the 1883 Krakatau eruption. J Volcanol Geotherm Res 9:359-378

Yokoyama I (1987) A scenario of the 1883 Krakatau tsunami. J Volcanol Geotherm Res 34:123-132 